\title{
Cumhuriyet Döneminde Ev Bahçelerindeki Değişimler ve Güncel Eğilimlerin İrdelenmesi
}

\author{
Hakan ALTINÇEKIÇ*, Esra ŞENTÜRK \\ istanbul Üniversitesi, Orman Fakültesi, Peyzaj Planlama ve Tasarımı Anabilim Dalı, 34473, istanbul, \\ Türkiye. \\ *e-mail:hakana@istanbul.edu.tr \\ Öz \\ Ev bahçeleri geçmiş, bugün ve yarın arasındaki ilişkileri kurmakta; bir dönemin tarihi ve kültürel özelliklerini, \\ toplumun yaşam koşullarını yansıtmaktadır. Bu çalışma ile Cumhuriyet Dönemi ev bahçelerinin değişimi ve \\ gelişimi anlatılmış sonrasında da güncel eğilimlerin belirlenmesi için istanbul-Hadımköy'deki Alkent 2000 \\ istanbul ile istanbul-Zekeriyaköy'deki Garanti Koza yerleşimlerindeki villa sakinleri ile anket uygulaması \\ yapılmıştır. Anketlerin sonuçları değerlendirilerek, konutlarda ikamet eden villa sakinlerinin sosyo-ekonomik \\ özellikleri ve bunların bahçelerine yansıtılması ile bahçe düzenlenmesindeki tercihleri ortaya konulmuştur. \\ Araştırma sonucunda, Cumhuriyet Dönemi ev bahçelerine ait tüm verilerin ve anket sonuçlarının \\ değerlendirilmesi yapılarak bu değerlendirmelere göre sonuçlar çıkarılmıştır ve gerekli öneriler getirilmiştir. \\ Anahtar Kelimeler: Cumhuriyet Dönemi, ev bahçesi, anket, peyzaj tasarımı, ev bahçesindeki değişim.

\section{Changes in Home Gardens and Investigation of Current Trends During the Turkish Republic Era}

\begin{abstract}
Home gardens establishes relationship among the past, the present and the future; and it reflects an historical and cultural characteristics of a special period and the lifestyles of the society. In this study, the changes and developments of home gardens at the Turkish Republic Era have been investigated. Following that a questionnaire survey have been conducted to the residents of Alkent 2000 Istanbul in Hadımköy and Garanti Koza in Zekeriyaköy Istanbul to determine current trends thereof. By means of the evaluation of the questionnaire results describe attitudes of those residents and their socio-economic features towards their own gardens as well as its land use and arrangements.

As a result of the research, evaluations are made about the determining of the examined home gardens at the Turkish Republic Era and all the results of the questionnaires and conclusions have been made according to these evaluations and required suggestions are offered.
\end{abstract}

Keywords: Turkish Republic Era, home garden, questionnaire, landscape design, changes in home garden.

\section{Giriş}

Bahçeler, her zaman insan hayatının bir parçası olup, değişik şekillerde doğadaki yerini almıştır. Örneğin, kutsal kitaplarda genellikle cennetin bir bahçe mekânı şeklindeki anlatımı, insanların dünyadaki yaşamlarında da birer küçük cennet mekânına sahip olma arzusunu doğurmuştur ve böylece insanlar dünya hakkındaki ideallerini adeta bahçe olarak adlandırılan mekânlarda yaratmaya çalışmışlardır. Çağlar boyunca bahçeler, insanların günlük hayatlarının aleladeliklerinden, sıkıntılarından kurtulup, tabiata ait varlıklarla sıkı ilişkiler kurabilecekleri bir çeşit sığınak olmuşlardır (Akdoğan, 1974). 
Özetle, bahçe; insanların doğayla bütünleştikleri, dinlendikleri, zevkli vakit geçirdikleri ve bunların yanında çeşitli sebze, meyve, ağaç veya çiçek gibi bitkisel öğeleri yetiştirebilecek yararlı kullanımlara imkân veren mekân olarak tanımlanabilir (Ertin, 2011).

Orta Asya'dan Yakın Doğu'ya uzanan topraklarda farklı ve köklü kültürler ile etkileşime giren Türkler, yaklaşık 1000 yıldır çekirdek Anadolu peyzajında yerleşik varlıklarını sürdürmektedirler. Bu uzun soluklu süreç kapsamında önce Küçük Asya'nın ve Orta Doğu'nun, sonra da Avrupa'nın farklı ulusları ile devinime girmiş olan Türk kültürü eklektik bir kimliğe bürünmüştür. Söz konusu bu kimlik, doğal bir sonuç göstererek, günlük yaşamın en değerli yaşam alanlarından biri olan ev bahçesine de temel bazı özellikleri ile yansımıştır. Bu bağlamda bahçe, evin bir uzantısı konumunda olup; sosyalleşmenin, öncelikli olan iş üretme ile beraber gerçekleştirildiği; aile bireylerinin rekreasyonel ihtiyaçlarını farklı eylemlerle gerçekleştirebilecekleri önemli ve vazgeçilmez bir mekân biçimine dönüşmüştür. İmparatorluğun sosyo-kültürel yapısına bağlı kurulmuş ekonomik sistemde, geniş ailenin ihtiyaçlarının yine aynı ailenin bireyleri tarafından karşılanması durumu ev bahçelerinin biçimlenmesinde en etkin rolü üstlenmiştir. Bu doğrultuda, Türk ev bahçelerinin birincil olarak nesnesel, ikincil olarak da manevi fayda elde etme prensibi ile şekillendiği ortaya çıkmaktadır (Wallece ve Küçükerbaş, 2016).

Türk yerleşimlerinde bahçe kavramı kent dokusu içerisinde konut, kasır, saray, yalı bahçeleri ve cami bahçeleri ile temsil edilmiştir. Doğanın yüksek seviyede manipüle edildiği Batı kökenli bahçe tasarımlarının tam tersine, Türk bahçelerinde doğal öğeler ön plandadır ve doğa bahçe kullanımlarında belirleyici olan temel unsur olarak kabul edilmiştir. Estetik öğelerden ziyade bahçeden faydalanma, üretkenlik, kullanımın maksimize edilmesi Türk bahçelerinin betimlenmesinde belirgin hale gelen pragmatik bir yaklaşım altını çizmektedir. Bahçenin temel unsuru olan gölge veren ağaçlar, çeşmeler, kameriyeler ve doğal kontürlere uyumlu bir biçimde şekillenen mekânsal kullanım Türk Bahçelerinin tipik karakteristiklerini oluşturmaktadır. Türk kentlerinde bahçeler kent dokusu içerisinde doğanın temsil edildiği bireysel alanlar olarak gelişmiştir (Akyol ve Kaya, 2016).

Bu çalışma Cumhuriyet Dönemindeki ev bahçelerini fotoğraf, bahçe planları, minyatür ve literatürler üzerinden irdeleyerek ortaya koymaktadır. Sonrasında Cumhuriyet Dönemi ev bahçelerindeki yaklaşımların günümüz yerleşim alanlarındaki ev bahçesi uygulamaları ile karşılaştırılması ve konuya ilişkin anket çalışması ile değişimlerin ve güncel eğilimlerin ortaya konulmasına çalışılmıştır.

\section{Materyal ve Yöntem}

Bu bölümde araştırma kapsamında seçilen konu ile araştırma sürecinde izlenen yöntem açıklanmıştır.

\subsection{Materyal}

Bu çalışmanın ana materyalini Cumhuriyet Döneminde ev bahçelerindeki değişimler ve güncel eğilimlerin irdelenmesi oluşturmaktadır. Öncelikle konuya ilişkin kaynaklar, çalışmalar incelenmiştir. Sonrasında da güncel kullanımlarındaki yeni yaklaşımları belirlemek amacıyla seçilen belirli alanlarda yapılan anketlerden elde edilen veriler de bu çalışmanın materyalini oluşturmaktadır.

\subsection{Yöntem}

Çalışmanın ilk aşaması; literatür taraması, veri toplama, inceleme, analiz ve değerlendirme çalışmalarından oluşmaktadır. Öncelikle araştırma konusu olan Cumhuriyet Dönemi ev bahçeleri ile ilgili yerli kaynaklar kütüphane kaynaklarından ve internet üzerindeki konu ile ilgili çalışmalardan ve çeşitli bildirilerden taranarak konunun kavramsal çatısı oluşturulmuştur. Doğru ve güvenilir bilgilere ulaşmak ve elde edilen bilgileri genelleştirmek için aynı konuda daha önce yapılan birden fazla kaynak irdelenmiştir. Yöntemin bu aşamasında özellikle, Akdoğan (1974), Eldem (1976), Kuş Şahin (2008), Wallece ve Küçükerbaş (2016) tarafından ortaya konan sınıflandırma ve verilerden yararlanılmıştır.

Araştırma konusu ile ilgili daha önce yapılan araştırmalar ve sonuçları incelendikten sonra, bir mantık çerçevesi içerisinde kriterler oluşturulmaya çalışılmıştır. Kriterlerin oluşturulmasından sonra, bu kriterleri doğrudan ölçmeye yönelik anket soruları hazırlanmıştır. Anket formunda elde edilmesi hedeflenen bilgiler, beş ana bölümde ele alınmıştır.

İstanbul'da son 15 yıldır yerleşimin artması ve son dönemlerde ev bahçesi eğilimlerini en açık biçimde ortaya koyması nedenleri ile örneklem alanları olarak Hadımköy ve Zekeriyaköy seçilmiştir. Her bir 
örneklem alanında, $25^{\prime}$ er adet olmak üzere, toplam 50 anket yapılmıştır. Anket formlarının tamamlanmasından sonra, her anket katılımcısının verdiği yanıtlara göre değişkenler tanımlanmış olup, istatistik analizi yazılım paketi programı olan IBM-SPSS programına veriler girilmiştir. Girilen verilerle ilgili temel istatiksel işlemler ile veriler arasındaki ilişkileri saptayacak analizler, grafikler yapılmıştır.

\section{Bulgular}

\subsection{Ev Bahçesindeki Değişimler}

Konut, insanoğlunu varoluşundan günümüze kadar, bulunduğu çevre ve toplum yapısı ile bütünleştiren, çevre ile uygunluk sağlayan ve günlük yaşam deneyimlerini şekillendirdiği bir öğe olarak algılanabilir. Özellikleri nedeniyle de konutlar, korunmuş alana sahip, özel kimlik taşıyan ve kişisel değer taşıyan mekânlar olarak da ifade edilebilir. Çoğu zaman konut ve ev kavramı birbirlerinin yerine kullanılmaktadır. Hasol (1993) konutu bir veya daha fazla insanın ikamet ettiği yer, mesken, ikametgâh olarak; evi ise sadece bir ailenin yaşamını sürdürebileceği konut olarak tanımlamaktadır (Kuş Şahin, 2008).

Türkiye'deki konut biçimlerinin gelişimi ve konut politikaları incelenirken karşılaşılan ortak yaklaşım konunun zamansal olarak 4 dönem içinde ele alınmasıdır. Bu zamansal bölünmeler, aslında Türkiye'deki toplumsal, ekonomik ve sosyal gelişmelerin konuta yansıması şeklinde düşünülebilir. Bu bölümde dönemlere ayırma;

\section{Cumhuriyet öncesi dönem,}

\section{Cumhuriyet'ten 1950 'lere kadar süren dönem,}

\section{1950'lerden 1980'lerin başına kadar süren dönem,}

4. 1980 sonrası dönem, şeklinde yapılmıştır. Ayrımı yapılan dönemlerin başında ve sonunda yaşanan gelişmeler, örneğin, Cumhuriyet'in kurulması, göç hareketinin başlaması, Beş Yıllık Kalkınma Planları ve çıkarılan kanunlar, konu dâhilinde önemli dönüm noktalarıdır. Bu çerçevede, konu üzerinde yapılan çalışmalarda genellikle İstanbul'daki gelişmeler ve örnekler ele alınmıştır. Bunun nedeni İstanbul'un hemen her dönemde ekonomik, toplumsal ve kültürel açıdan ülkenin en önde gelen kenti olması ve değişimlerin ilk olarak İstanbul'da gözlenmesidir (Saygıcı, 2004).

Insanların konutlarında rahat, güvenli, mutlu bir şekilde yaşayabilmeleri için, konutun olduğu kadar çevresinin de düzenlenmesi gerektiği ortaya çıkmıştır. Günümüzde yeşil alanların giderek azalması sonucunda insanların yeşile olan özlemlerini gidermek, doğayla olan ilişkilerini arttırmak, aynı zamanda konutlara estetik değer kazandırmak için konut bahçeleri önem kazanmıştır (Taşkan, 2014).

Geçmişte ve günümüzde yoksul-varlıklı her konut sahibi, küçük-büyük avlu veya bir bahçeye sahip olmak istemiştir (Altunkasa, 1998). Bu istek, bahçenin konutun ayrılmaz bir parçası olarak düşünülmesinde ve ona göre şekillenmesinde büyük bir etken olmuştur (Ertin, 2011).

Sosyo-kültürel faktörlerin etkisi ile Türk konutunda oluşan bahçe anlayışı, konutun biçimlenmesinde etkisini göstermiştir. Konutlarda zemin katlar genel olarak bahçeye açık, sokağa kapalıdır. Mahremiyet ile gelen gizlilik olgusu, bahçenin dış ortama, yani sokağa kapalı olmasını gerektirir. Bu da bahçeyi ve konutu çevreleyen bahçe duvarları ile sağlanır. Bir anlamda, bahçe planlaması konutu, konut planlaması da bahçelerin biçimlenmesine etki etmektedir (Gedikli, 1993).

Eldem (1976)'e göre Türk bahçe düzenlerinde mutlak var olan en önemli bir özellik iç ve dış mekân kaynaşmasıdır. Konut ile bahçe bir bütün olarak düşünülmekte olup, bahçe açık havada oturmak amacı ile yapılmış bir konut bölümüdür. Binanın bir kısmının direklikler üzerinde bahçeye taştığı taşlık denilen yarı açık mekân ile bahçe ve bina arasındaki ideal bağlantı sağlanmıştır. Bu serin ve loş mekân hem evin hem bahçenin en çekici yeri konumunu almıştır. Bazen de bu geçiş, üstü saçak veya çardakla örülmüş mekânlar vasıtasıyla gerçekleşmektedir.

Osmanlı'da ev ve bahçe düzeni, aile yapısı ile sosyal ve ekonomik durumu doğrultusunda, korunma ve iklim temeline oturan bir yapıda olmuştur. Sosyal durum içinde en etkin unsur i̇slamiyet ve onun temel felsefesi ile Türklerin geleneksel yaşam tarzı sayılabilir. Bunlar ev ve bahçenin şekillenmesinde 
önemli etkenlerdir. Bu nedenle Osmanlı'da ev ve bahçe mahrem (gizli), içe dönük "ev-bahçe" birlikteliği vardır. Hemen her iklimde (Akdeniz, Orta Anadolu) yapılan evlerin mutlaka bir giriş bölümü, ön bahçesi yani "hayat"ı ya da "avlu" su bulunmaktadır. Avlu, etrafı bütünüyle yüksek duvarlarla çevrili, çiçekli ve ağaçı bir yerdir (Gültekin, 1998). Kapalı, mahrem, sakin, gölgeli, yeşil ve özel bir açık hava yaşama mekânı olarak değerlendirilen bahçe avluları özellikle Türkler tarafından eski devirlerde çok benimsenmiş ve uygulanmıştır. Kapalı, mahrem, sakin, gölgeli, yeşil ve özel bir açık hava yaşama mekânı olarak değerlendirilen bahçe avluları özellikle Türkler tarafından eski devirlerde çok benimsenmiş ve uygulanmıştır (Tanrıverdi, 1987).

Anadolu Türk kentlerinde her konutun küçük bir yeşil avlusu veya bahçesi vardır. Kentin yeşili konutun bahçesindedir. Konuttan ayrılmayan bir yeşil anlayışı vardır. Bir Türk atasözü de bunu çok güzel belirtmektedir. "Kişi bina yaptığı yere ağaç da diker". Le Corbusier, bu durumu İstanbul için şöyle ifade etmektedir: İstanbul'daki evler ağaçlarla çevrilmiştir, insan ve doğa arasındaki cazip dostluk... İstanbul'da her yerde ağaçlar olup onların arasından mimarlığın soylu örnekleri yükselir (Gedikli, 1993).

Türk bahçesi işlevsellik, yaşama mekânı olması ve düzende yalınlığı ile karakterize edilmektedir. Yapı ile bahçe arasında simetriyi yaratan belirgin bir eksen bulunmamaktadır. Türk bahçesi, gezinti bahçesinden çok oturma bahçesi olduğu için, bahçenin çekici veya uygun yerlerine oturma, dinlenme yerleri yapılmıştır. Oturma yerleri, sade bir taş sofadan başlayarak kameriye, taht ve hatta göz alıcı bir köşk şeklinde de olabilmektedir (Avcl, 2005). Türkler, yaşanabilirlik için gerekli olan yeme, içme, eğlenme, dinlenme, dolaşma, uyuma gibi ihtiyaçlarının hemen hemen tümünü bahçede gerçekleştirmektedirler. Dış mekânda oturma ve yemek yeme alanları ile küçük yapılar, ana yapı ile bütünlüğü sağlamaktadır. Eğimli alanlarda teras bahçeleri oluşturulmakta, teraslardan her biri farklı işlevlerle değerlendirilmektedir. Bu nedenle Türk bahçelerinin en önemli karakteristiği, bahçede yer alan plan elemanlarının simetriye dayalı bir tasarım ortaya koymamasıdır. Bu durum, bahçenin sadece seyredilecek değil aynı zamanda yaşanacak mekânlar olarak yaratılmasına neden olmaktadır. Doğaya olan saygı, doğal form ve düzenden hoşlanma duygusu, bahçe tasarımında izlenmektedir (Öztan, 2004).

Konuta bağlı dış mekân; bahçe şekillendiyse, birleştikleri kısmın üstü bir saçak veya çardakla örtülmüş, yerleri taş döşenmiş, yarı açık bir geçit oluşturmuştur. Yazın sofra bu taşıkta kurulmaktadır. Taşlığın önünde fıskiyeli veya selsebilli havuz yer almış, çevresine saksılar içerisinde çiçekler dizilmiştir. Bahçe, havuzdan çıkan su arıklarıyla sulanmıştır. Zemin çoğunlukla eğimli olduğundan, bahçe sedlerle düzenlenmiştir. Her sedde bir veya birkaç çiçek türüne yer verilmiştir. Çiçek tarhları yalın tür ve renk karmaşıklığı göstermemektedir. Bir tarha yalnız ya gül ya da lale dikilmiştir. Çiçek tarzlarının ötesindeki bazı sedlerde sebze de yetiştirilmiştir. Sebzelerle, meyve ağaçları daima çiçek tarhları yanında yer almıştır. Ağaçlar, genellikle bahçeyi çevreleyen duvar boyunca dikilmiştir ve bahçenin dış gözlerden uzak oluşuna psikolojik de olsa bir katkıda bulunmuştur. Ayrıca gölge vermesi açısından büyük boylu ve geniş tepe yapısına sahip ağaçların yer yer tek başına dikildiği görülmektedir (Evyapan, 1972).

Cumhuriyet öncesi Türk bahçeleri, alçak gönüllü ölçülerde, bu evrende cennet bahçesinin yaratılmasına uğraşan yalın ama kavramca zengin bir bahçedir. Bazen bağ, av sahası veya koruluklarla bitişik olabilse de, ana bahçe küçük ölçülerde hemen hemen daima loş, gölgeli ve yazın kavuruculuğundan korunmuş, zihinsel dinlenme mekânlarıdır (Evyapan, 1974).

Erdem (1990)'e göre, Cumhuriyet Öncesi Türk konut bahçelerini üç grup halinde inceleyebiliriz. Bunlar:

- Saray bahçeleri

- Konak ve Köşk bahçeleri

- Yalı bahçeleridir.

Saray bahçeleri ile en güzel örneklerinin yansıtıldığı Türk bahçelerinde doğaya uygunluk, oluşan güzelliğin ana kaynağını teşkil etmiştir (Evyapan, 1974). 
Tarihi saray bahçeleri Türk bahçe karakteristiğine uygun şekilde iç ve dış bahçe bütünü olarak düzenlenmiştir. Bu bahçeler av, spor faaliyetleri ve diğer eğlenceler için kullanırken bir yandan da buralarda sarayların ihtiyaçlarını karşılamak üzere çiçek, sebze ve meyve yetiştirilmiştir (Kartal, 2009).

Ev, konak ve yalı bahçelerinden günümüze kadar bozulmamış bir şekilde kalanlar azdır. Bazen ev veya yalı vardır ama bahçeye ait izler kalmamıştır bazen de bahçeye ait duvar veya bir havuz kalıntısı mevcuttur fakat ev yok olmuştur (Eldem,1976).

Cumhuriyet öncesi dönemlerde iklim koşullarına göre, her devirde kentlerimiz içinde hemen hemen her ailenin ekonomik düzeyine uygun olarak, içinde meyve ağacı, sebze veya çiçek tarhı, çiçek saksıları, bir çeşme veya havuzu olan konutla bitişik bir avlusu, ya da özellikle kullanışlılığı küçük veya büyük bir bahçesi, bağı olmuştur. Avlu veya bahçe konutun dışa uzantısı sayılmış; yazın yaşamın büyük bir kısmı içinde geçtiğinden yüksek duvarlarla çevrilip kişiye özel konumu korunmuştur (Erdem, 1990).

Oturma birimleri, bahçe duvarları, su elemanları, kapılar, merdivenler, taşlık ve bitkiler, genellikle Türk bahçelerinde bulunan bahçe elemanlarıdır. Bunlar, yapının bulunduğu yerin ekolojik şartlarına, yörenin geleneklerine, yapı sahibinin ekonomik durumuna göre değişmektedir (Avcı, 2005).

Günümüze kadar ulaşan minyatürlerden ise kameriyeler, havuzlar, serviler, meyve ağaçları, laleler, kuş kafesleri ve bitki tarhlarının çok sık kullanıldığı anlaşılmaktadır. Minyatürlerdeki bahçe tasvirlerinde, bahçeler rengarenk çiçeklerle süslüdür. Lale, gül, sümbül, nergis gibi çiçeklerin yanı sıra bahar çiçekleri, zeminde çeşitli kır çiçeklerinin tasvirleri, o döneme ait bilgileri açık olarak vermektedir (Eldem, 1976).

Cumhuriyet öncesi devirlerde genellikle az katlı, bahçeli bir düzen içindeki yapıların, köşk, konak ve villaların geniş koruluk ve bahçeler içinde yer alması, yeşile duyulan gereksinimi azaltmıştır. Kentlerde bulunan bahçelik ve bostanlık alanlar, parsellenerek çok katlı yüksek yapılara dönüşmüş ve bahçe içerisinde yeşil ile iç içe yaşayan konutlar, yerini bu yeşilden yoksun beton yığınlarına bırakmak zorunda kalmıştır. Eski köşklere ait arazilerin zamanla parsellenmesi ile daha küçük bahçeli konutlar oluşmuştur. Daha sonraları ise bu bahçeli konutlarında daha küçük parsellere ayrılması ile bu yerleşim bölgeleri, yüksek katlı bloklardan oluşan bahçesiz, yeşilliğe hasret konut alanları haline gelmiştir (Erdem, 1990).

Özellikle kırsal alanlarda belirgin biçimde ortaya çıkan yapısal farklılıklar sonucu (mekân kurgusu, yapı malzemesi, yapım biçimleri vb.) yöreye özgü olarak gelişen, geleneksel kırsal konut olarak tanımlayabileceğimiz konut yapıları ve onların birlikte oluşturdukları dokular olmuştur (Gürer, 2003).

Geleneksel yaşamın, dini inanç ve davranışların hâkim olduğu geleneksel konutlarda, Cumhuriyet döneminin modern anlayışıyla gelen ve dinin günlük yaşamdaki gücünü azaltan yaklaşım, toplumdaki kadın-erkek ayırımının ve görsel mahremiyet ilkelerinin büyük çapta geçerliliğini yitirmesine sebep olmuştur. Sanayi döneminde ise, göçlerle ve nüfus artışıyla birlikte şehir dokusunu oluşturan geleneksel konutlar bozulmaya başlamış; ataerkil aile düzeninin değişmesiyle birlikte, bu düzene göre planlanan geleneksel evlerin fonksiyonları da değişmiştir (Zeybekoğlu, 2005).

Erken Cumhuriyet Döneminde, ülke bütününde var olan konutların büyük bir bölümü eski ve yıpranmıştır. Yerleşim ile ilgili pek çok sorun bulunmaktadır. Ancak, ülkedeki ekonomik sorunların baskınlığı, konut ve yerleşim sorunlarına eğilinmesini zorlaştırarak ihmal edilmesine neden olmuştur. 1923'lerde başlayan Dünya ekonomik bunalımı sorunların çözümünü daha da güçleştirmiştir (Mutluer, 2000).

Ayrıca 1950 sonrası dönemde toplum içinde giderek yaygınlaşan apartmanda yaşama isteği ve yaşamsal gereksinimlerin gerçekleştirilmesinde meydana gelen değişimler (yemek, yeme, oturma, uyuma eylemleri için özelleşmiş mekân arayışları) geleneksel konutun plan düzenini değiştirmiştir. Geleneksel konutların ıslak hacim düzenleri de günümüz anlayışından oldukça uzak olduğundan kullanııının bu mekânlarda yeni düzenlemelere gitme eğilimleri de artmıştır (Perker ve Akıncıtürk, 2011). 
İs merkezlerinin ve ticaret alanlarının kent merkezlerinde giderek artması sonucu buralardaki konut alanları yerini ticaret alanlarına bırakmak zorunda kalarak, kent merkezinden daha uzakta bulunan yerlere taşınmışlardır. Böylece kent merkezinden uzakta yeni yerleşim bölgeleri oluşmaya başlamıştır. Özellikle sanayi bölgelerinde şehrin havası insan sağlığını tehdit eder duruma geldiğinden ve insanlar açık havaya, gürültüden uzak sakin bir hayata ve doğaya özlem duyduklarından, tamamen şehir dışında bahçeli konutlara yönelmişlerdir (Ertin, 2011).

1936 yılında ortaya çıkan bahçeli evler girişimi ile ilk toplu konut örnekleri görülmektedir. Jansen 12 Kasım 1935 tarihinde 300 konutluk yerleşme alanı planı oluşturmuştur. 17.12.1937'de Jansen'in bahçeli evler tasarımında kullandığı parsel düzeni ve yoğunluk ilkeleri İmar İdare Heyeti 292 sayılı kararı ile Ankara planında Yenişehir, Cebeci ve kooperatif sahası için genelleştirilmiş̧ir. Bunun sonucu olarak Türk evlerinin biçimsel değeri terk edilmiş onun yerine batıdaki gelişmelere koşut konutlar üretilmiştir. Bu sistemde genel olarak ön bahçeler caddeye veya sokağa açık mahremiyeti koruyamayan yasayanlar tarafından kullanılamayan daha çok dekoratif özellik taşıyan alanlar olarak karsımıza çıkmaktadır. Arka bahçeler ise caddeden uzak, kapalı konumdadır (Aydıngün ve Sıtkı, 1997).

Ülkemizde bahçe düzenlemeleriyle ilgili yasal durum 03.05.1985 tarihli 3194 Sayılı İmar Kanunu'na göre belirlenmiştir. Bahçe mesafeleri, bahçe parsel genişlik ve derinlikleri ve bahçe duvar yükseklikleri bu kanunun maddeleri ile belirlenmiştir (Yeşil ve Yılmaz, 2007). Günümüzde değişen yaşam şartları, artan nüfus ve sosyo-ekonomik durum insanların daha çok, daha az alanlarda ve neredeyse doğadan yoksun, üst üste konulan beton yığınlarında oturmaya mecbur bırakmıştır (Ertin, 2011).

Bahçelere, günümüzde taşıdığı anlam ve güncel örnekler perspektifinden baktığımızda, geleneksel bahçelerden farklı karakterlere rastlamaktayız. Önceleri genellikle fayda amacı güden yani tarımsal amaçla kullanılan bahçeler, zaman içerisinde kişilerin zevk, kültür ve ekonomik yapılarına göre biçimlenmiştir. Nüfus artışı ve göçler sonucu ortaya çıkan konut sorunu bahçeli konumdaki yaşama mekânlarını, ortak yaşama mekânları bulunan, yüksek katlı yapılardan oluşan, toplu konut alanlarına yöneltmiştir. Günlük yaşamlarında işten eve gidip gelen bir ortamda yaşayan kişilerin rekreatif isteklerini gerçekleştirebilecekleri, kentin boğucu ve kalabalık ortamından uzaklaşabilecekleri sakin ve dinlendirici açık ve yeşil mekânlara gereksinimleri vardır (Erdem, 1994). Bu alanlar günlük ihtiyaçlar için kolay ulaşabilecekleri mekânlar olarak konuta en yakın açık yeşil alan olan bahçeyle bütünleşerek günümüz bahçelerini oluşturmaktadır. Gelişen ve değişen teknik imkânlar sonucunda, bahçe tasarımında kullanılan tüm öğelerde, malzeme ve kullanım tekniği olarak büyük değişimlerin olduğu ve çeşitlerinin çoğaldığı gözlenebilmektedir. Bu değişim ve gelişimlerin dışında bitki kompozisyonundaki ithal bitkilerin ve yeni tasarım anlayışlarının girişi ile aynı zamanda su öğesinin yüzme amaçlı olarak kullanılmaya başlanması, bahçedeki fonksiyonel anlamda en belirgin değişimler olarak görülmektedir (Kayakent, 1999).

Toplumun kültürel geçmişini, estetik anlayışını temsil eden ve ayrıca ruhi ve fiziki sağlığını olumlu etkileyen bahçe kavramına tarih boyunca büyük önem verilmiştir. Fakat son dönemde yaşanan göç ve hızlı nüfus artışı kent dokusunun değişmesine, pastoral peyzajların ve ihtişamlı bahçelerin yerini, barınma ihtiyacına yönelik konut-bahçe tipolojilerinin almasına yol açmıştır. Müstakil bahçe anlayışı ortak yeşil alan kullanımına dönüşmüştür. Bu dönüşümde insanların zevk, kültür ve ekonomik durumları önemli rol oynamaktadır (Kaya ve Akyol, 2016).

Daha önce göç, plansız ve yasadışı kentleşme, altyapı eksiklikleri gibi ihtiyaçlardan doğan, kendi içinde çağdaş yasam standartlarını sağlayan özgün projelere olan talep, özellikle 1999 yılında deprem felaketiyle hissedilir düzeyde artmıştır. Deprem, konut piyasasının dinamiklerini etkilemiş, değişen pazar koşullarına uygun yeni konseptlerin oluşumunu hızlandırmıştır. Depremin ardından, proje ve inşaat şirketlerinin güvenirliliği ön plana çıkmış, büyük ve saygın inşaat şirketleri ve gayrimenkul yatırım ortaklıklarının yaptığı projelere talep artmıştır. Bugün İstanbul konut piyasası değerlendirildiğinde genellikle tercih edilen, rezidans olarak adlandırılan ve çeşitli servisleri bünyesinde barındıran konut kuleleri, şehir dışı az katlı ve bahçeli konut tipleri ile şehir içinde mimari ve konum olarak özel konseptli projelerdir. İstanbul'un kuzey kısımlarında yer alan düşük yoğunluklu konut yerleşimlerine talep artmış, yüksek kaliteli ve güvenilir projeler prim yapmaya başlamıştır (Yahşi, 2007). 
Yukarıda sayılan faktörlerin ön plana çıkması, nitelikli konut açığı bulunan İstanbul'da inşaat şirketlerini harekete geçirmiştir. Gayrimenkul yatırım ortaklıkları; İstanbul ve yakın çevresinde lüks konut yapımına ağırlık verirken, TOKi ve İstanbul Büyükşehir Belediyesi toplu konut yapımına ağılık vermiştir. Bu bağlamda İstanbul içerisinde yapılan konut projelerinin 6 ana konut bölgesi ve çevresinde odaklandığı ve yoğunlaştığı görülmektedir. Bu bölgeler; Ümraniye-Çekmeköy, AtaşehirKozyatağı, Kemerburgaz-Maslak, Kurtköy-Pendik, Tuzla-Maltepe, Beykoz-Riva, Bahçeşehir-Halkalıİkitelli'dir (Ünlükara, 2008).

Günümüzde konut alıcısının konut alırken göz önünde bulundurduğu bir takım seçim kriterleri bulunmaktadır. Özellikle de iyi bir peyzajın olması konut fiyatlarını artıran önemli etkenlerin başında gelmektedir. Giderek betonlaşan yaşam alanlarında müstakil konutların her birinin kendine ait bir bahçesinin bulunması ve yaşayanlara kimi zaman nefes alacak kimi zaman da kendi sebzelerini yetiştirebilecek vb. aktivitelere olanak sağlayan konutlarda fiyatlar yükselmektedir. Şekil 1' de toplu konuttan müstakil konuta doğru çıkıldıkça gözlenen fiyat artışı farklı konut tiplerine göre geliştirilen fiyat piramidinde açıkça gözlenmektedir.

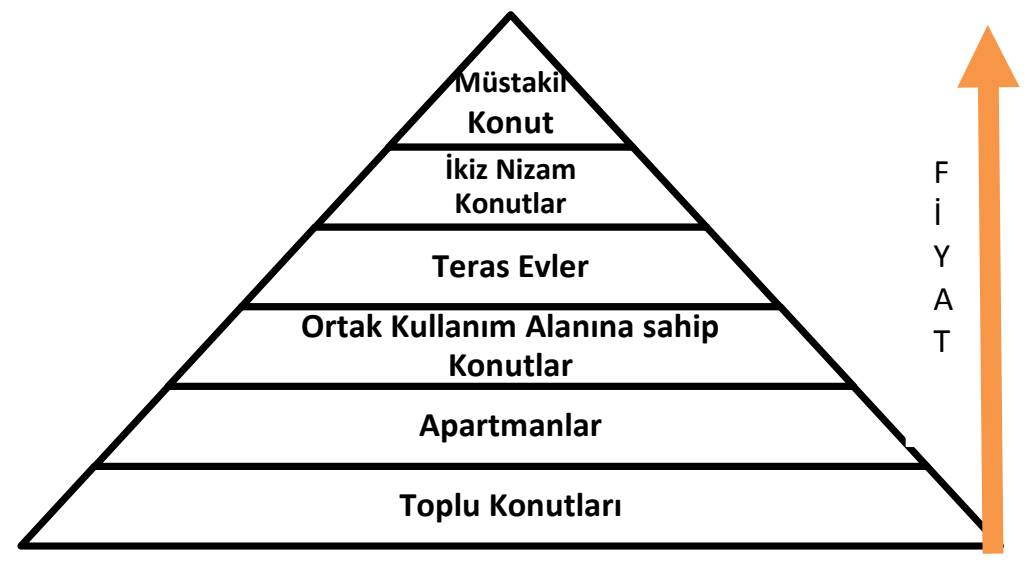

Şekil 1. Farklı konut tiplerine göre fiyat piramidi (Chen, 2006; Ünlükara, 2008).

Konutlarda bahçe oluşumunu etkileyen faktörler kısaca; iklim ve arazi yapısı, yerel yapı malzemesi ve ikamet edecek bireylerin geleneksel ev kültürü olarak özetlenebilir. Anadolu'nun her bölgesinde özellikle kırsal kesimlerdeki müstakil konutlar, çoğunlukla arsa alanına bağlı olarak değişik büyüklükte bahçeye sahiptirler. Bazı yörelerde bahçede mutfak bulmaktadır. Bu uygulamaya Marmara ve Kuzey Anadolu bölgelerinde ender rastlanmaktadır (Kuş Şahin, 2008).

Modern anlamda bahçe-konut uygulamalarında bahçe ile konut arasındaki sınırlar çok belirgin değildir. Çalı ve çiçekler ile süslenmiş balkonlar, iç avlular bahçeye açılan geniş ve büyük camlı kapı ve pencereler, dış mekânla iç mekân arasında organik bir bağ oluşturabilirler (Tanrıverdi, 1975). Örneğin, oturma odasından arka bahçenin güzel görünüşü rahatça seyredilebilmeli, yemek odasından terasa rahatça geçilebilmeli, gerektiğinde açık havada yemek yeme, çay ve kahve içebilme olanağı bulunmalıdır. Bu bakımdan bahçe planlanması ile yaşam alanı planlaması (konut) birlikte yapılmalıdır. Fakat ülkemizde genellikle konut yapıldıktan sonra bahçeler planlanmaktadır. Bu durum doğal olarak bahçe oluşturulması sırasında oluşabilecek hata ve sorunların çoğu kez giderilememesine neden olmaktadır (Gülez, 1989).

\subsection{Kullanıcıların Güncel Eğilimlerinin Belirlenmesine Yönelik Anket Uygulamaları}

Ev bahçelerinin kullanımındaki güncel eğilimlerin belirlenmesi için gerçekleştirilen anket çalışmaları, İstanbul-Hadımköy'deki Alkent 2000 isstanbul ile i̇stanbul - Zekeriyaköy'deki Garanti Koza yerleşimlerindeki villa sakinleri ile gerçekleştirilmiştir. Güncel kullanım eğilimlerinin irdelenmesi amacı ile gerçekleştirilen anket çalışması 5 bölümden oluşmaktadır. Birinci bölümde anket katılımcılarının bahçe kullanım ve aktiviteleri analiz edilmiştir. İkinci bölümde anket katılımcılarının konutlarına ilişkin tercih sebeplerinin ulaşım ve bağlantılarla ilişkisi sorgulanmıştır. Üçüncü bölümünde ev bahçeleri ile ilgili konfor ve imaj olguları analiz edilmiştir. Anketin dördüncü bölümünde katılımcıların ev bahçeleri ile ilgili sosyalleşme olanakları ile ilgili sorular yer almaktadır. 
Son olarak beşinci bölümde ise anket katılımcılarının sosyo-ekonomik yapıları belirlenmeye çalışılımıştır.

\subsubsection{Kullanım ve Aktivitelere iliş̧kin Verilerin Değerlendirilmesi}

Ev bahçesi kullanımı ile ilgili sorulan sorularda, bahçe mekânının kullanım yoğunluğu ve aktivitelere ilişkin kullanıcıların eğilimlerinin ortaya konması hedeflenmiştir. Katılımcıların \%56'sı "Bu yerleşim alanında en çok hangi yeşil alanlardan faydalanıyorsunuz?" sorusuna konut bahçesi, \%44'ü de bahçe dışındaki yeşil alanlar (spor alanları, parklar) şeklinde yanıtlamıştır (Şekil 2).

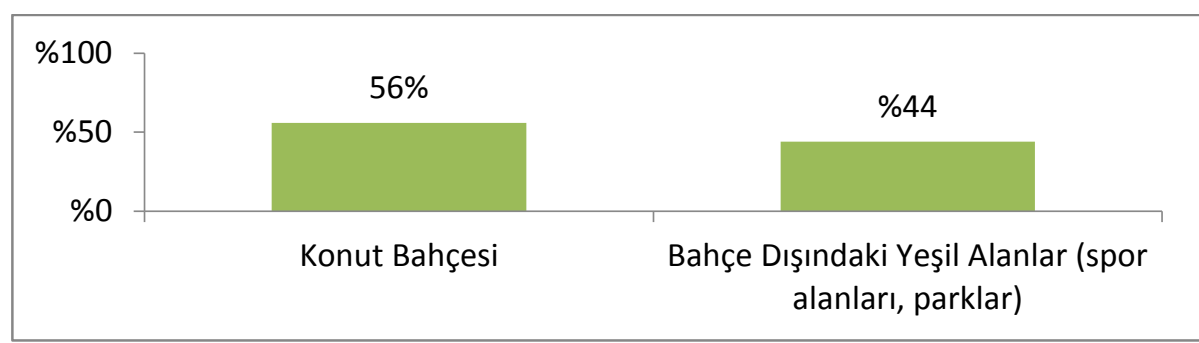

Şekil 2. "Bu yerleşim alanında en çok hangi yeşil alanlardan faydalanıyorsunuz?" Sorusuna verilen cevapların grafiği.

"Konutunuzun bahçesinde olmasını istediğiniz fonksiyon alanları nelerdir? (En fazla 5 tercih)" Sorusuna verilen cevaplar incelendiğinde, katılımcıların \%59 oranla istedikleri fonksiyonların dinlenme ve spor alanları olduğu görülmektedir. Bunu takip eden fonksiyon ise $\% 48$ oranla çocuk oyun alanı ve otopark-garajdır. Ayrıca katılımcılar tarafından konut bahçesinde olması istenilen fonksiyonlar arasında \%44 oranla yaya yolları, \%33 oranla kış bahçesi; \%30 bitki gösteri alanı, \%26 sebze bahçesi, \%22 meyve bahçesi, \%15 yüzme havuzu, \%11 süs havuzu yer almaktadır. Türk ev bahçesinin en önemli unsurlarından olan açık-yeşil alan kullanımı ve dinlenme alanları ile net algılanabilir yolların, uygulanan anketlerdeki kullanııı istekleri ile örtüştüğü görülmektedir (Şekil 3).

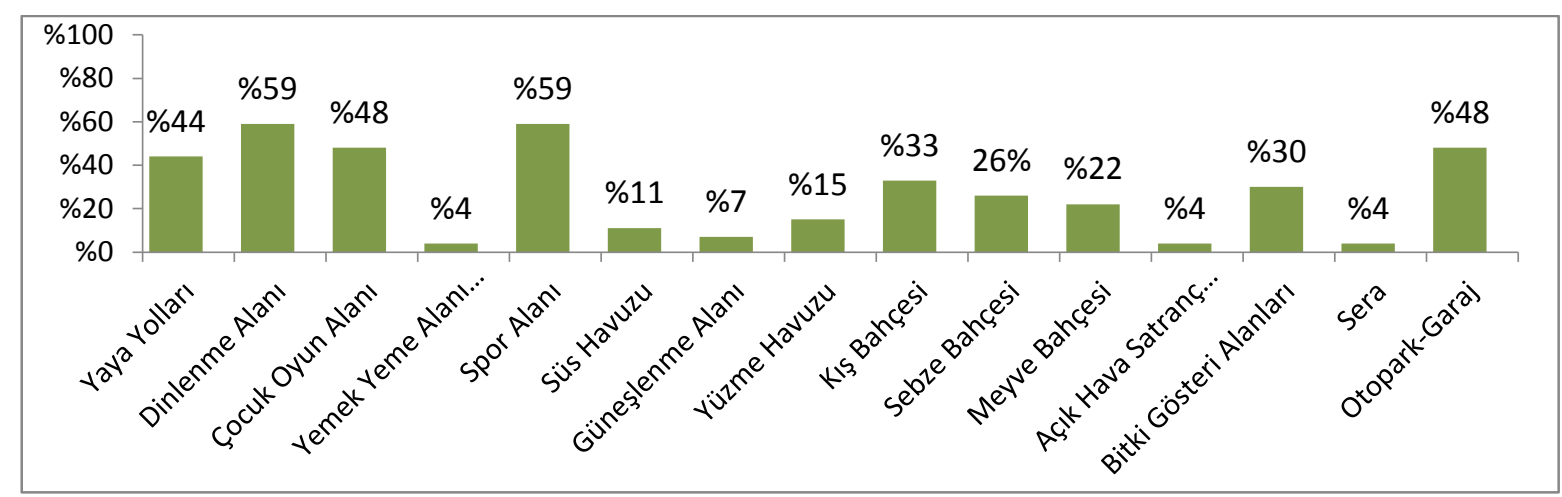

Şekil 3. "Konutunuzun bahçesinde olmasını istediğiniz fonksiyon alanları nelerdir? (En fazla 5 tercih)" Sorusuna verilen cevapların grafiği.

"Konutunuzun bahçesini en çok hangi mevsimde kullanıyorsunuz?" Sorusuna verilen cevaplar incelendiğinde, katılımcıların bahçelerini $\% 40^{\prime} l i k$ oranla en çok yaz mevsiminde kullanıldığı görülmüştür. Ayrıca katılımcılar konut bahçelerini \%30 dört mevsim, \%26 ilkbahar, \%4 de sonbaharda kullanırken, kış mevsiminde kullanımın olmadığı belirlenmiştir (Şekil 4).

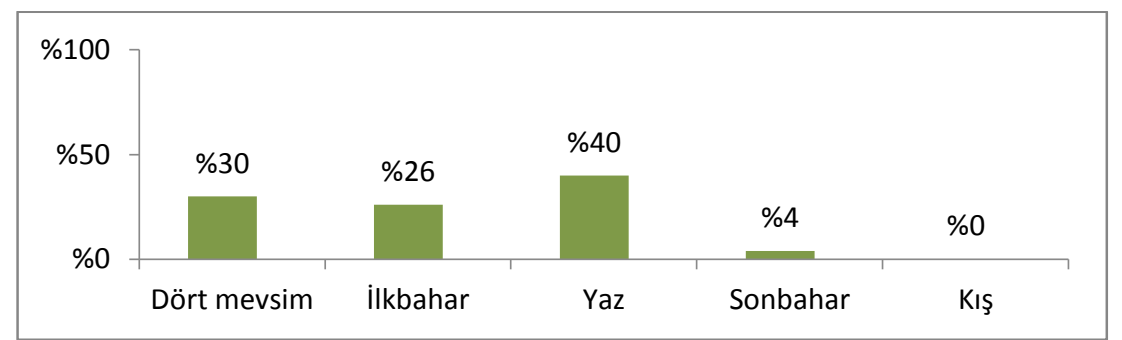

Şekil 4. “Konutunuzun bahçesini en çok hangi mevsimde kullanıyorsunuz?” Sorusuna verilen cevapların grafiği. 
Konutunuzun bahçesini daha çok haftanın hangi günlerinde kullanıyorsunuz? Sorusuna verilen cevaplar \%52 hafta sonu, \%22 her zaman, \%19 değişken, \%7 hafta içi şeklindedir (Şekil 5). Burada konut bahçesinin çoğunlukla hafta sonu kullanılan mekânlar olduğu görülmektedir.

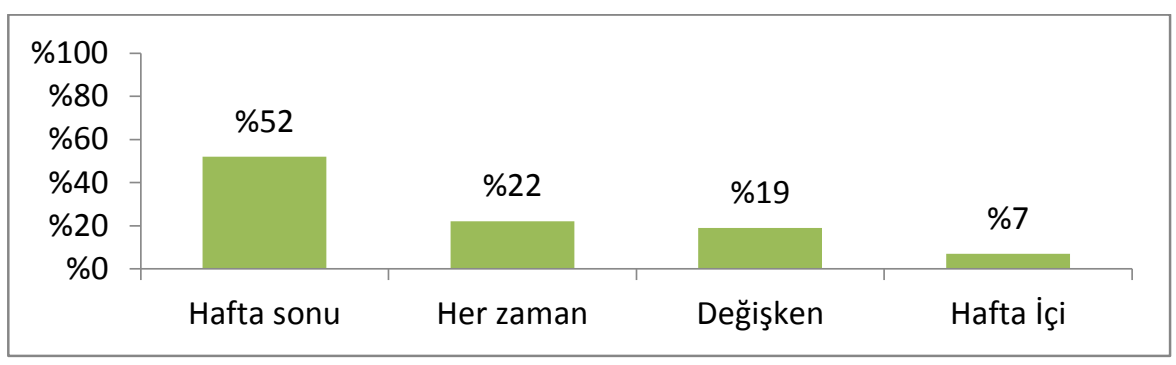

Şekil 5. "Konutunuzun bahçesini daha çok haftanın hangi günlerinde kullanıyorsunuz?" Sorusuna verilen cevapların grafiği.

"Konutunuzun bahçesini daha çok günün hangi saatlerinde kullanıyorsunuz?" Sorusuna verilen cevaplar incelendiğinde anket katılımcılarının bahçelerini en çok \%42 oranla öğleden sonra ve akşamüzeri, bu oranı \%8 ile sabah-öğle arası ve öğle saatleri takip etmektedir. Gece kullanımının olmadığı görülmüştür (Şekil 6).

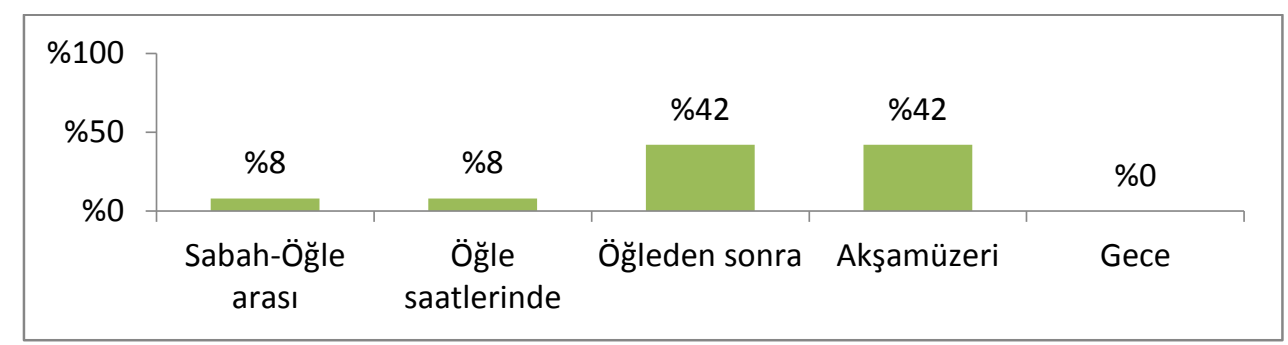

Şekil 6. "Konutunuzun bahçesini daha çok günün hangi saatlerinde kullanıyorsunuz?" Sorusuna verilen cevapların grafiği.

"Konutunuzun bahçesini günde ne kadar süre kullanıyorsunuz?" Sorusuna verilen cevaplar \%44 ile 12 saat, \%30’la 1 saatten az, \%22, 2-4 saat ve \% 4, 4 saatten fazla şeklindedir (Şekil 7).

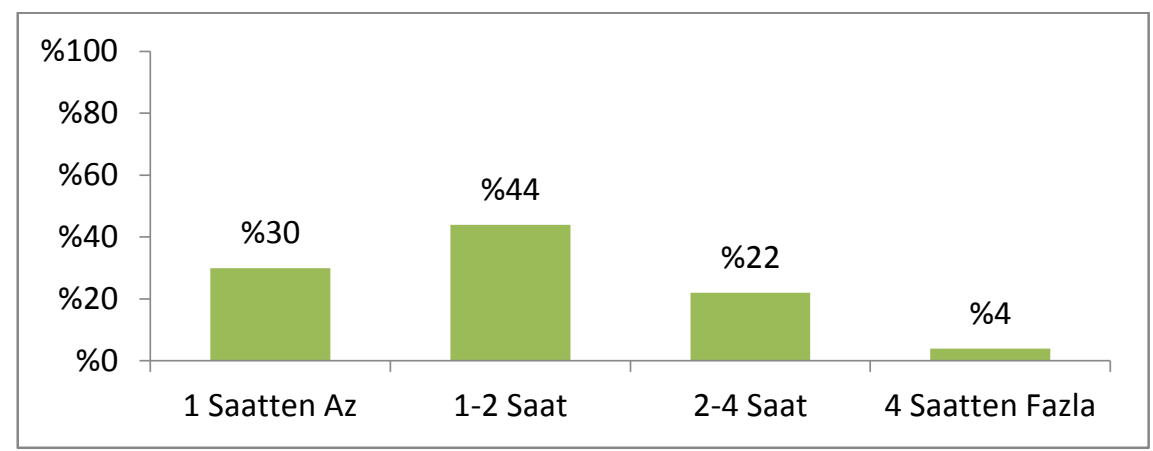

Şekil 7. “Konutunuzun bahçesini günde ne kadar süre kullanıyorsunuz?” Sorusuna verilen cevapların grafiği.

\subsubsection{Ulaşım ve Bağlantılarına ilişkin Verilerin Değerlendirilmesi}

Anket çalışmasının bu bölümünde katılımcıların konut bahçeleri ve konutlarının kent içindeki konumlarının ulaşım ve bağlantı olanaklarına ilişkin yaklaşımları ortaya konmuştur.

"Bu yerleşim alanında sizce otopark sorunu var mı? Sorusuna katılımcıların \%65'i evet, \%35'i hayır cevabı vermiştir. Katıımcıların çoğunluğu otoparkı olan bir konut alanında yaşamasına rağmen bu alanda otopark sorunu olduğu görüşündedir (Şekil 8). Bu durum pek çoğunun iki veya daha fazla aracı olmasından kaynaklanmaktadır. 


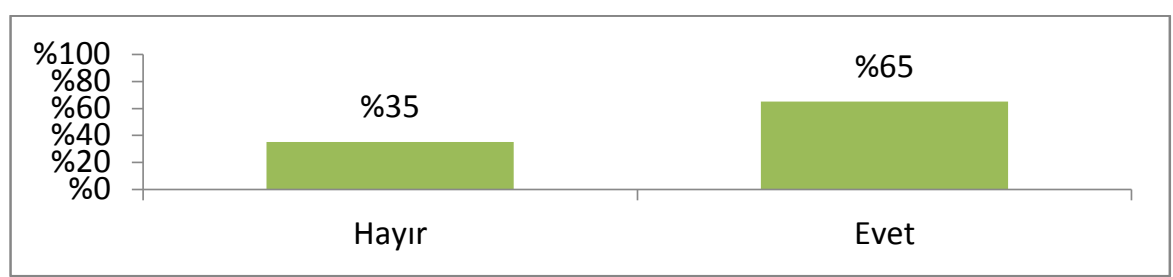

Şekil 8. "Bu yerleşim alanında sizce otopark sorunu var mı?" Sorusuna verilen cevapların grafiği.

“Özel aracınız var mı? Var ise kaç adet?" Sorusu ile anket katılımcılarının \%62'sinin 2, \%26'sının 3 özel araca sahip olduğu \%12'sinin de 1 araca sahip olduğu belirlenmiştir (Şekil 9).

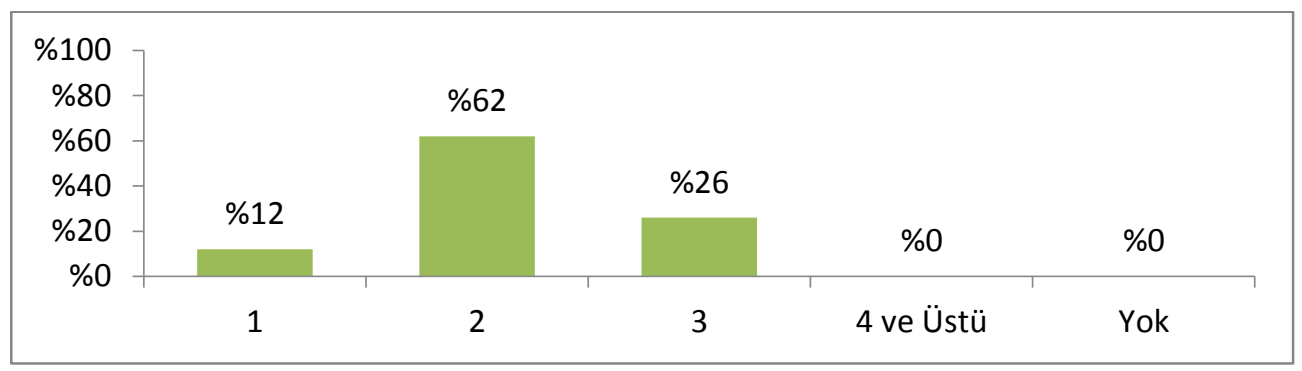

Şekil 9. “Özel aracınız var mı? Var ise kaç adet?” Sorusuna verilen cevapların grafiği.

“Konutunuzun kullanımına ait özel otopark/garajınız var mı?” Sorusuna katılımcıların \%62'ü evet, \% 38 'i hayır cevabı vermiştir. Hayır cevabı veren kullanıcıların 2 veya daha fazla aracı olduğu düşünülmektedir.

\subsubsection{Konfor ve İmaja İlişskin Verilerin Değerlendirilmesi}

Konfor ve imaj, İnsanların bir alanı bir fonksiyonu kullanırken ki tecrübelerine dayanmaktadır. Güvenlik ve bakım gibi konular da park, bahçe konforu ve imajın şekillenmesinde önemli rol oynamaktadır.

"Konutunuzun bahçesinde bulunmasını istediğiniz donatı elemanları hangileridir? (En fazla 5 tercih)" Sorusuna katılımcıların \%70'i oturma grupları (bank), \%63'ü bitkisel elemanlar, \%44 çocuk oyun elemanları ve spor ekipmanları, \%41 aydınlatma elemanları, \%33 döşeme kaplaması ve su elemanları (yüzme havuzu, süs havuzu vb.), \%30 gölgeleme elemanı (pergola), \%4 plastik objeler (heykel) cevapları alınmıştır (Şekil 10).

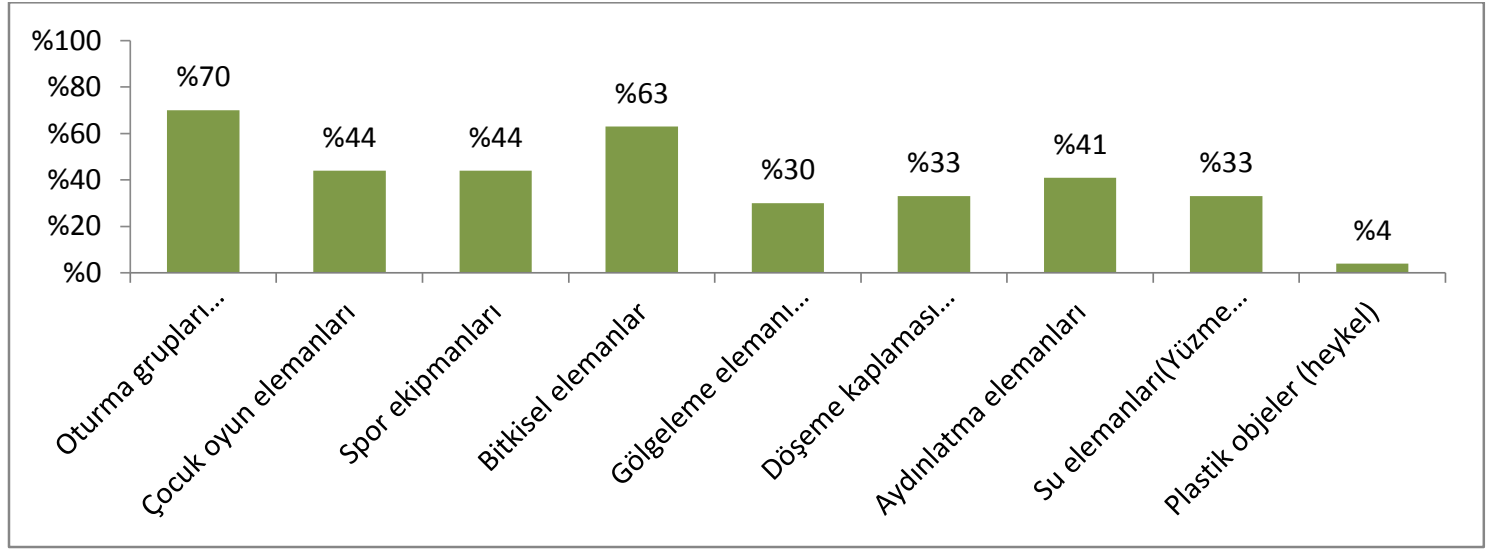

Şekil 10. "Konutunuzun bahçesinde bulunmasını istediğiniz donatı elemanları hangileridir? (En fazla 5 tercih)" Sorusuna verilen cevapların grafiği.

"Konutunuzun bahçesi sizce bakımlı mı?" Sorusuna ise \%59 kısmen bakımlı, \%41 bakımlı cevapları verilmiştir. Bakımsız cevabı veren ise yoktur (Şekil 11). 


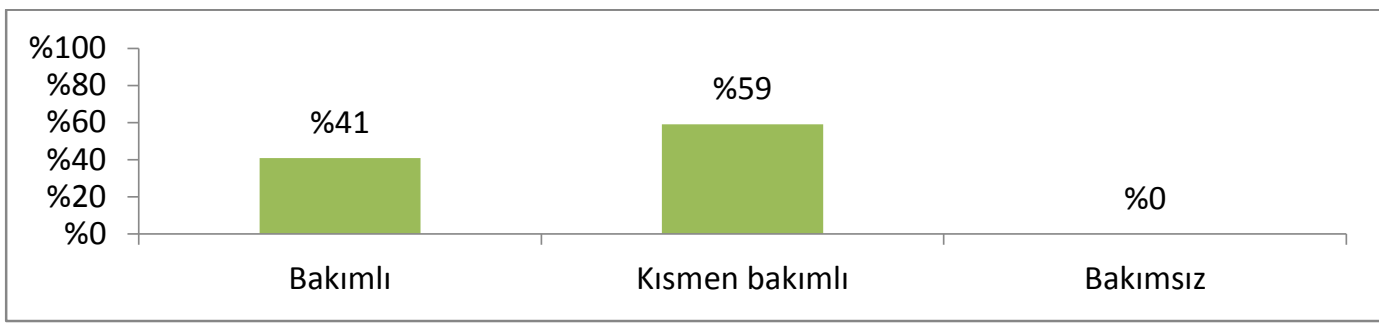

Şekil 11. "Konutunuzun bahçesi sizce bakımlı mı?” Sorusuna verilen cevapların grafiği.

"Konutunuzun bahçesindeki bakım sorunları nelerdir? (En fazla 3 tercih)" Sorusuna \%50 oranında verilen cevap ile köpek pisliklerinin sorun olduğu anlaşılmaktadır. Bu cevabı \%46 tamir gerektiren döşemeler ve \%42 bitkilendirilmiş alanların bakımsızlığı, \%29 hasarlı yapı ve donatılar, \%4 toplanmayan çöpler takip etmektedir (Şekil 12).

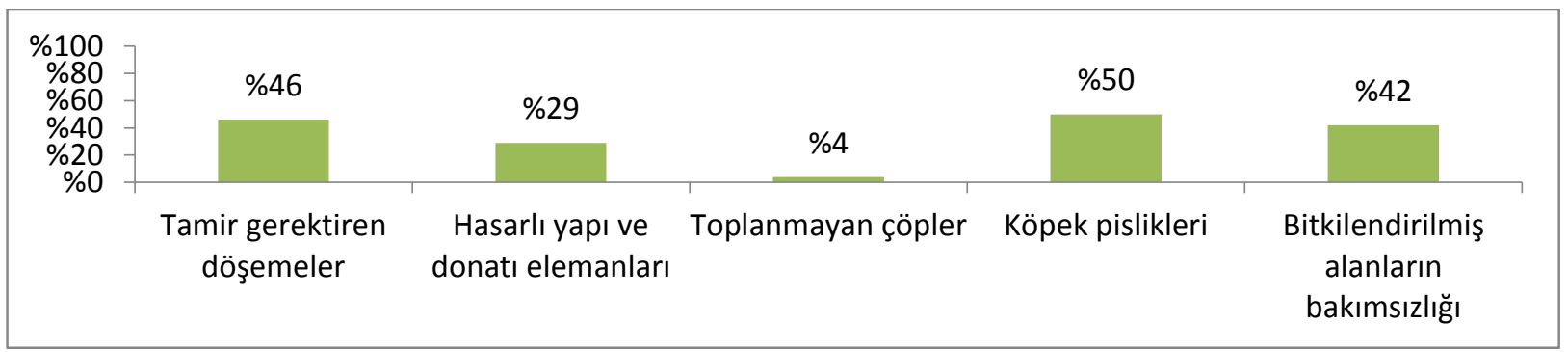

Şekil 12 "Konutunuzun bahçesindeki bakım sorunları nelerdir? (En fazla 3 tercih)" Sorusuna verilen cevapların grafiği.

"Bahçenizde en çok bulunmasını istediğiniz bitki türleri nelerdir? (En fazla 5 tercih)" Sorusuyla istenilen bitki türünün \%93 oranla çiçekli ağaçlar, \%58 iğne yapraklı ağaçlar (çam türleri), \%54 çim alanlar, \%50 mevsimlik çiçek, \%42 geniş yapraklı ağaçlar, \%15 yer örtücü, \%4 de çalılar ve sarılııı/tırmanıcı bitkiler olduğu belirlenmiştir (Şekil 13).

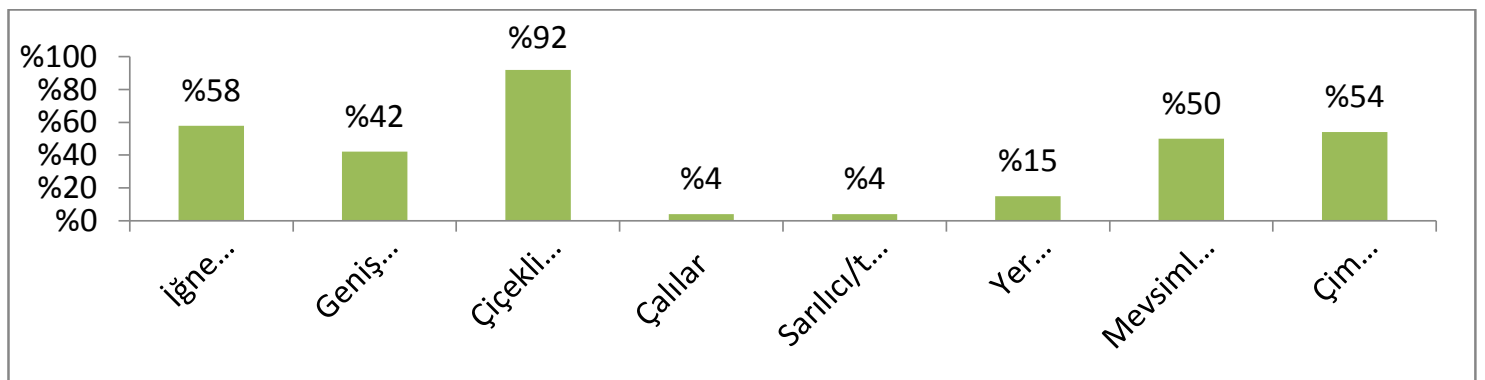

Şekil 13. "Bahçenizde en çok bulunmasını istediğiniz bitki türleri nelerdir? (En fazla 5 tercih)" Sorusuna verilen cevapların grafiği.

“Bahçe düzenlenmesinde kullanılan bitki türlerinin menşei sorulduğunda, katılımcıların \%56'sı yerli türler cevabını vermiştir. Katılımcıların \%32'si ise bilgisi olmadığını ifade etmiştir (Şekil 14). Bu soruya verilen yanıtların çoğunlukla yerli türler çıkmasına, katılımcıların bitki türlerini İstanbul'daki fidanlıklardan alması neden olmuştur. Oysa yapılan gözlemlerde çoğunlukla ithal türlerin kullanıldığı saptanmıştır.

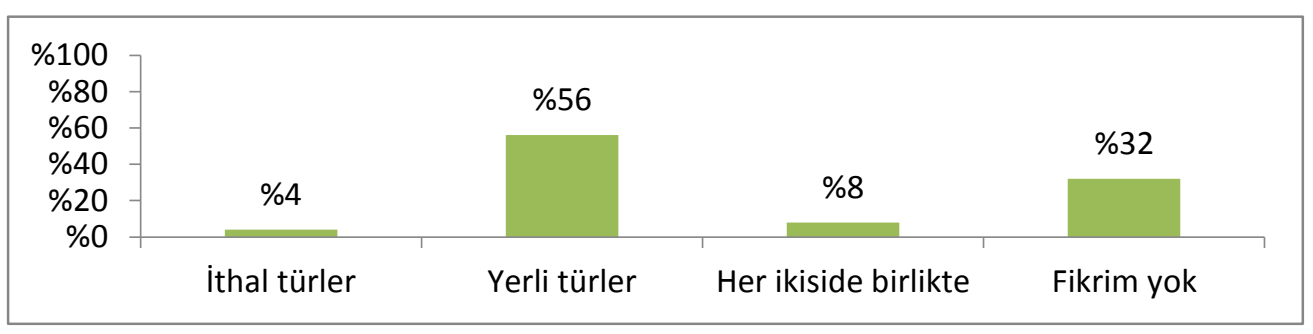

Şekil 14. "Bahçenizin düzenlenmesinde kullanılan bitki türlerinin menşei nedir?” Sorusuna verilen cevapların grafiği. 
"Konut bahçeniz düzenlenirken yakın bahçesindeki komşu bahçelerle ve diğer yeşil alanlarla görsel uygunluğu değerlendirildi mi? Sorusuna katılımcıların \%77'si evet, \%23'ü hayır cevabı vermiştir (Şekil 15).

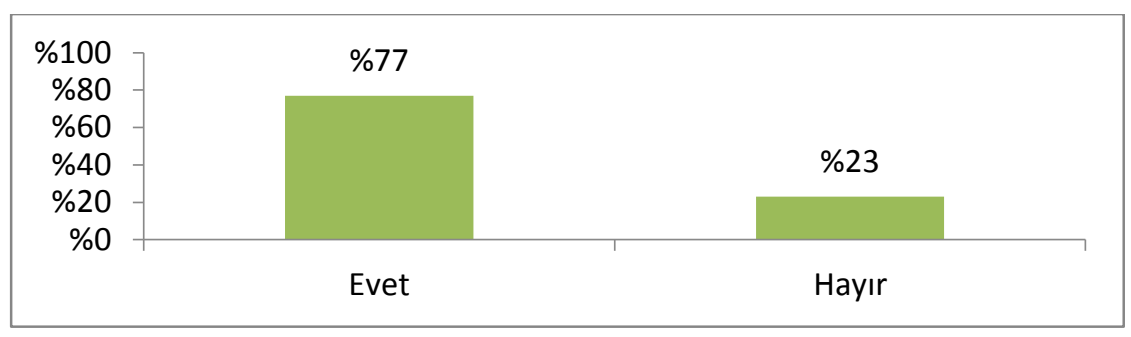

Şekil 15. “Konut bahçeniz düzenlenirken yakın bahçesindeki komşu bahçelerle ve diğer yeşil alanlarla görsel uygunluğu değerlendirildi mi?" Sorusuna verilen cevapların grafiği.

\subsubsection{Sosyalleşme Olanaklarına ilişkin Verilerin Değerlendirilmesi}

"Bu yerleşim alanında komşuluk ilişkilerini nasıl buluyorsunuz?" Sorusuna katılımcıların \%44 orta ve kötü, \%12 iyi olarak cevap vermiştir (Şekil 16). Oysa Türk kültüründe komşuluk ilişkisi oldukça önemlidir ve ev bahçesindeki sofa veya taşılı gibi alanların başta gelen işlevlerinden biri de komşu görüşmeleri, kalabalık sofralar, uzun sohbetler için mekân oluşturmalarıdır.

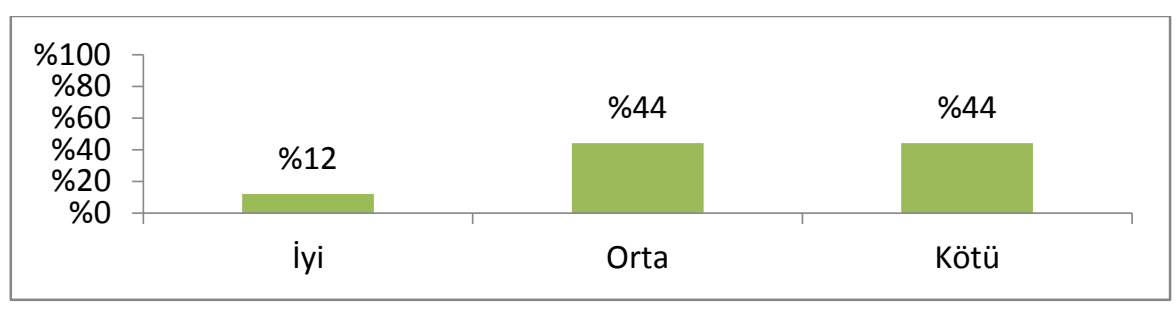

Şekil 16. "Bu yerleşim alanında komşuluk ilişkilerini nasıl buluyorsunuz?" Sorusuna verilen cevapların grafiği.

Anket katılımcılarının \%63'ü burada yaşayanların sosyal, ekonomik ve kültürel yönden birbiri ile kısmen uyumlu olduğunu \%21'i uyumlu olduğunu, \%16'sı uyumsuz olduğu görüşündedir (Şekil 17).

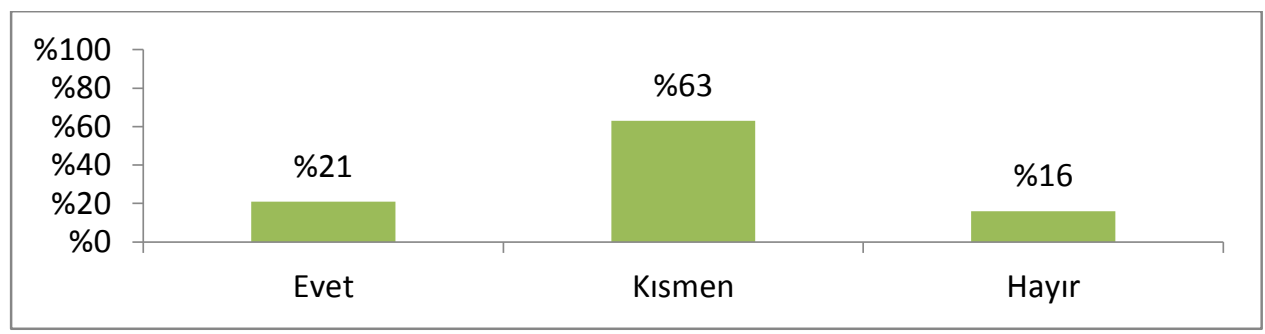

Şekil 17. "Sizce burada yaşayanların sosyal, ekonomik ve kültürel yönden birbiri ile uyumlu mu?" Sorusuna verilen cevapların grafiği.

"Konutunuzun bahçesini zaman zaman komşularınız ile birlikte de kullanıyor musunuz?" Sorusuna \% 54'ü hayır kullanmadığını, \%46'sı da evet diyerek kullandığını belirtmiştir (Şekil 18).

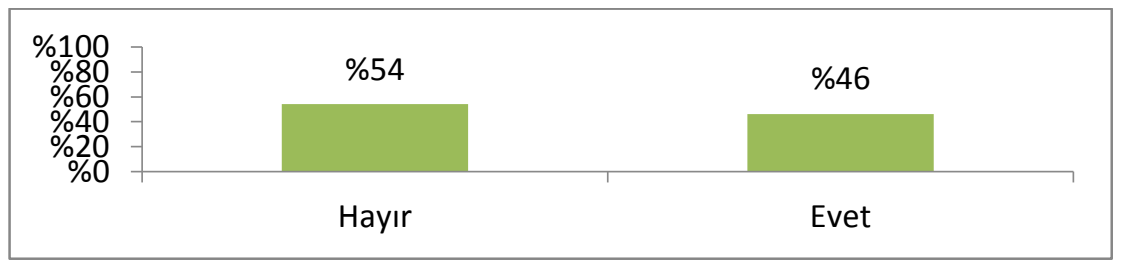

Şekil 18. "Konutunuzun bahçesini zaman zaman komşularınız ile birlikte de kullanıyor musunuz?" Sorusuna verilen cevapların grafiği.

"Bahçeli konutunuzun yer aldığı bu yerleşim alanında oturmayı tercih etmenizin sebebi nedir? (En fazla 5 tercih)" Sorusuna verilen cevaplar \%80 açık ve yeşil alanların olması, \%76 zemin ve yapının sağlam olması, \%64 planlı yerleşime sahip olması, \%48 sessiz sakin olması, \%24 alışveriş olanaklarının 
iyi olması, hava kirliliğinin olmaması ve prestiji yüksek bir semtte olması, \%20 ilerde değer kazanacak yerde olması ve işyerine yakınlığı, \%16 eğitim merkezine yakınlığı şeklindedir (Şekil 19).

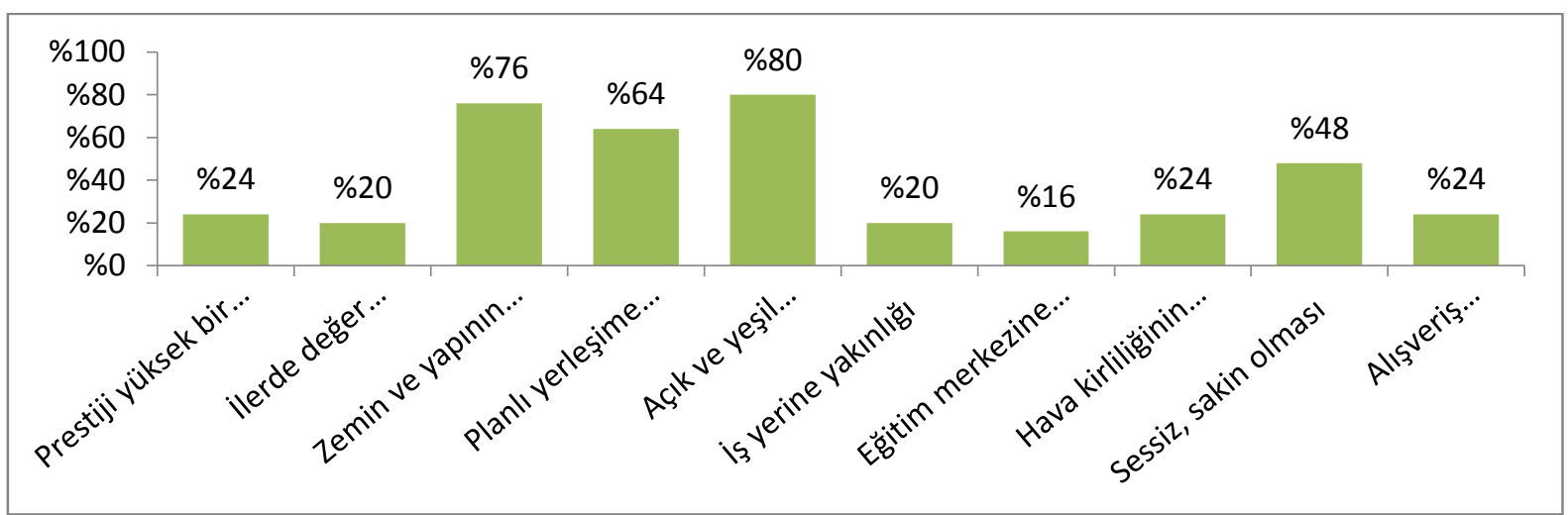

Şekil 19. "Bahçeli konutunuzun yer aldığı bu yerleşim alanında oturmayı tercih etmenizin sebebi nedir? (En fazla 5 tercih)" Sorusuna verilen cevapların grafiği.

"Evinizin yakın çevresinde yer alan özel bahçeniz haricindeki dış mekânlara düzenleme ve bakım açısından müdahale etmek ister misiniz?" Sorusuna \%72 hayır, \%28 evet cevabı verildiği gözlenmiştir (Şekil 20).

\begin{tabular}{|c|c|c|}
\hline \multirow{2}{*}{$\begin{array}{r}\% 100 \\
\% 80 \\
\% 60 \\
\% 40 \\
\% 20 \\
\% 0\end{array}$} & $\% 28$ & $\% 72$ \\
\hline & Evet & Hayır \\
\hline
\end{tabular}

Şekil Hata! Belgede belirtilen stilde metne rastlanmadı..1: “Evinizin yakın çevresinde yer alan özel bahçeniz haricindeki dış mekânlara düzenleme ve bakım açısından müdahale etmek ister misiniz?" Sorusuna verilen cevapların grafiği.

Katılımcıların "Bahçenizin sınırlarının belirginleştirilmesi konusundaki görüşleriniz nelerdir?" Sorusuna cevapları \%62 oranında kafes tel ile çevrelenmesini isterim, \%31 bitkisel çit uygulanmasını isterim, \%4 duvarlarla çevrelenmesini isterim ve \%3'ü sınırların belirginleşmesini istemem şeklinde olmuştur (Şekil 21).

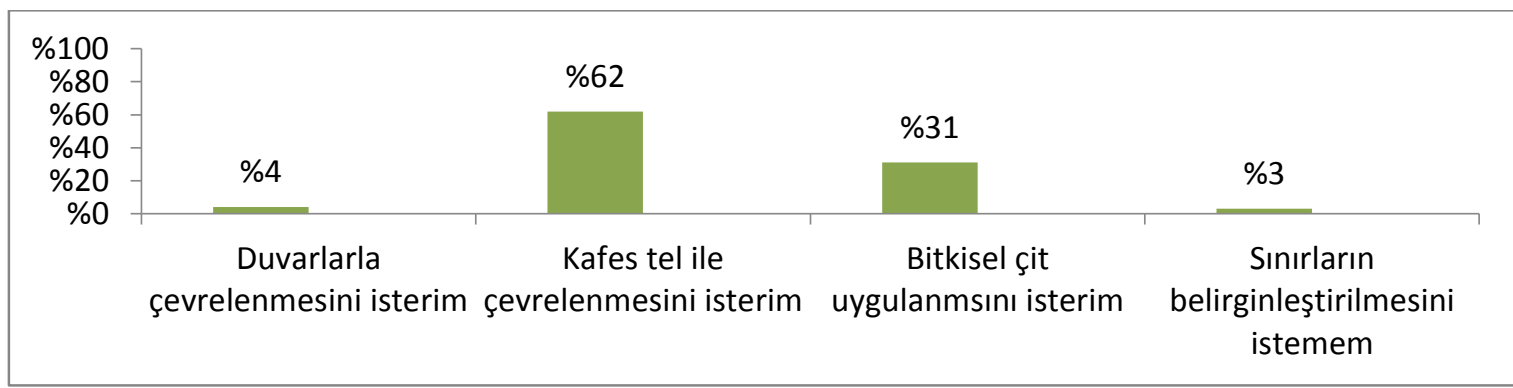

Şekil 21. "Bahçenizin sınırlarının belirginleştirilmesi konusundaki görüşleriniz nelerdir?” Sorusuna verilen cevapların grafiği.

"Peyzaj düzenlemesinin gerekliliğine ve konuta görsel, ekonomik vb. birçok değer kattığına inanıyor musunuz?" Sorusuna \%92 evet, \%8 hayır cevabını vermiştir. Katılımcıların tamamına yakınının peyzaj düzenlenmesinin öneminin farkında olduğu anlaşılmaktadır (Şekil 22). 


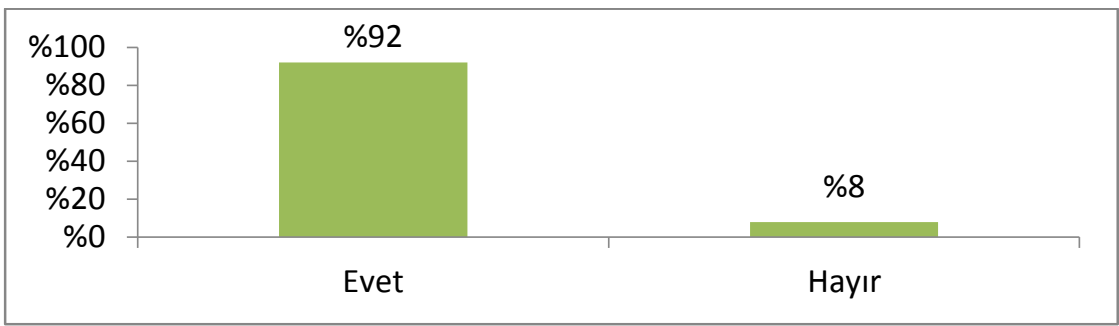

Şekil 22. “Peyzaj düzenlemesinin gerekliliğine ve konuta görsel, ekonomik vb. birçok değer kattığına inanıyor musunuz?" Sorusuna verilen cevapların grafiği.

"Bahçenizin peyzaj düzenlenmesi kim tarafından yapılmıştır?" Sorusuna katılımcıların \%42'si bahçıvan tarafından, \%32'si peyzaj mimari, \%21'i diğer, \%5'i de ziraat mühendisi cevabını vermiştir (Şekil 23).

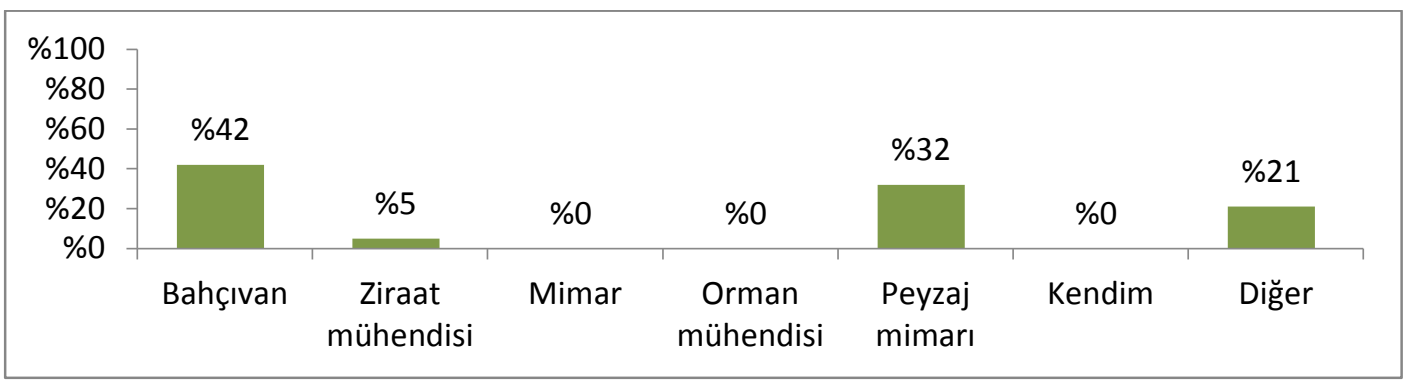

Şekil 23. "Bahçenizin peyzaj düzenlenmesi kim tarafından yapılmışırı?" Sorusuna verilen cevapların grafiği.

\subsubsection{Sosyo-Ekonomik Yapıya İlişkin Verilerin Değerlendirilmesi}

Ankete katılan bireylerin \%70'i erkek, \%30’u kadındır (Şekil 24).

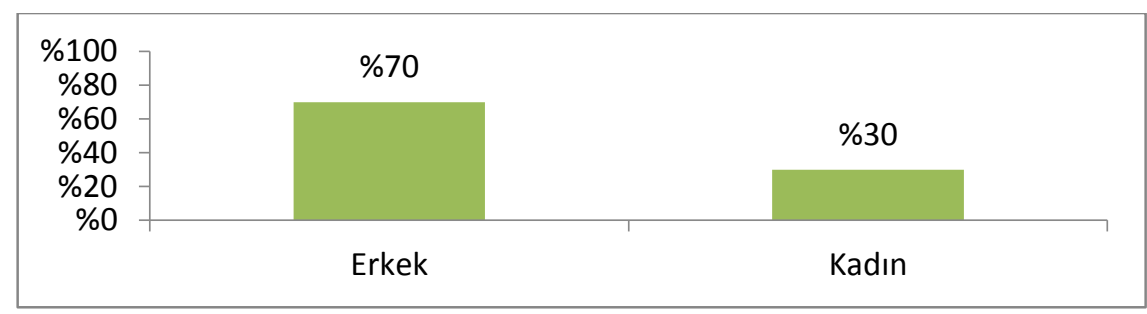

Şekil 24. Katılımcıların cinsiyet dağılımını gösteren grafik.

Katılımcıların yaş dağııımları incelendiğinde 16-24 yaş aralığında hiç katılımcı olmamasının yanı sıra \% 73 oranla çoğunluğunu 41-50 yaş aralığında olduğu belirlenmiştir (Şekil 25).

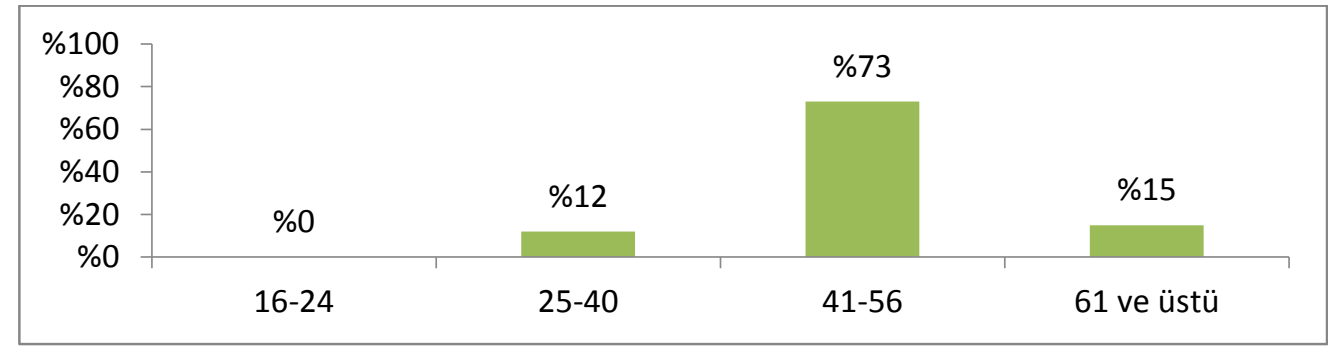

Şekil 25. Katılımcıların yaş dağılımları grafiği.

Ankete katılan bireylerin eğitim durumları incelendiğinde katılımcıların \%77'si üniversite mezunu, \% 12 'sinin ise lise mezunu ve diğer (Yüksek lisans, doktora) eğitim düzeyine sahip olduğu görülmektedir (Şekil 26). 


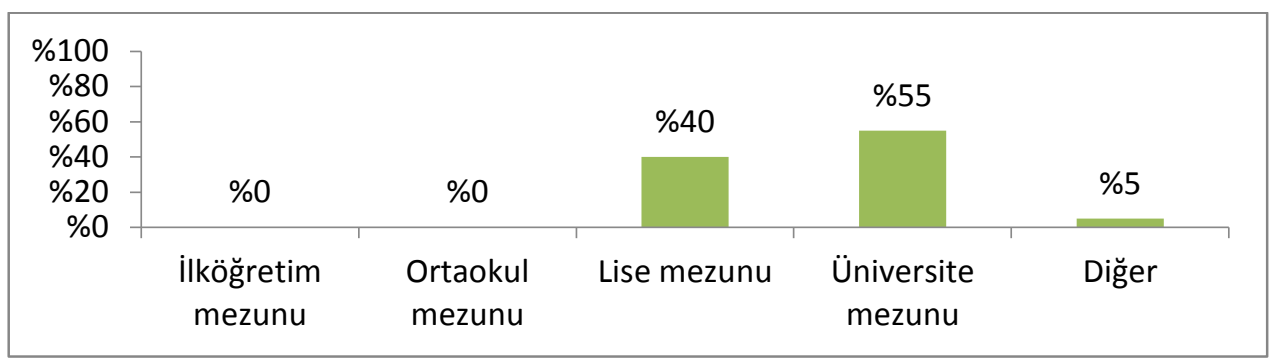

Şekil 26. Katılımcıların eğitim durumu grafiği.

Katılımcıların meslekleri incelendiğinde $\% 50$ 'sinin emekli, \%15'inin memur, serbest meslek ve diğer, \%5'i de ev hanımından oluştuğu belirlenmiştir (Şekil 27).

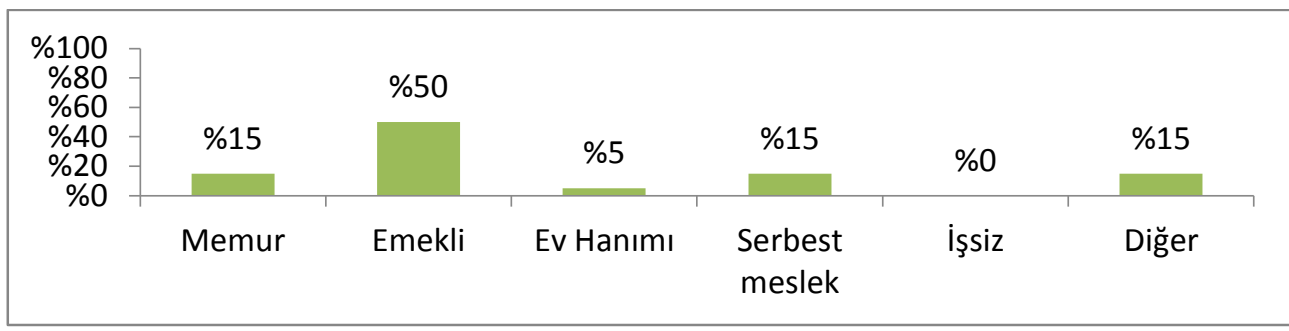

Şekil 27. Katılımcıların meslek dağılımların grafiği.

"Hanenizin (tüm bireyler dâhil) aylık toplam geliri ne kadardır?" Sorusuna katılımcıların \%35'inin 16000-20000 TL, \%30'unun 11000-15000 TL, \%22'sinin 0-10000 TL, \%9'unun 21000-25000 TL, \% 4'ünün de 26000-50000 TL cevabı verdiği belirlenmiştir (Şekil 28).

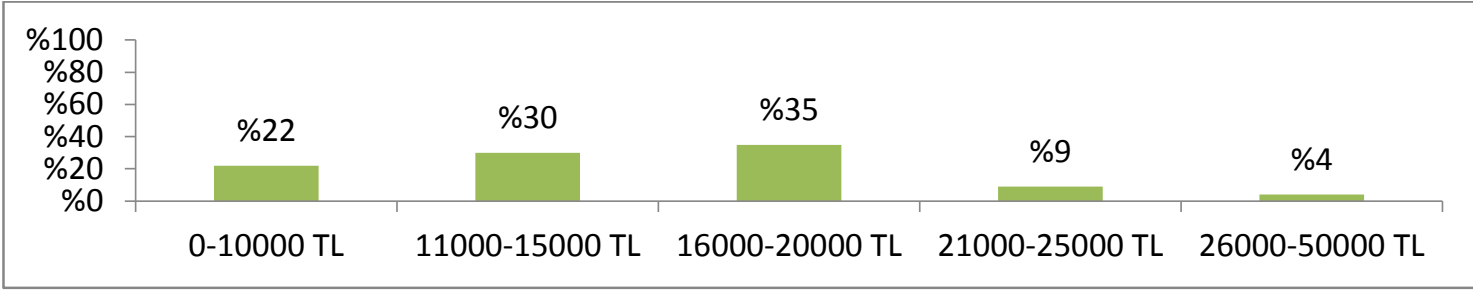

Şekil 28. “Hanenizin (tüm bireyler dâhil) aylık toplam geliri ne kadardır?” Sorusuna verilen cevapların grafiği.

“Kaç yıldır bu konutta oturuyorsunuz?” Sorusuna katılımcıların \%46'sı 10 yıl ve üstü, \%20'si 7-9 yıl, \% 17 'sinin de 0-3 ve 4-6 yıl cevabı verdiği gözlenmiştir (Şekil 29).

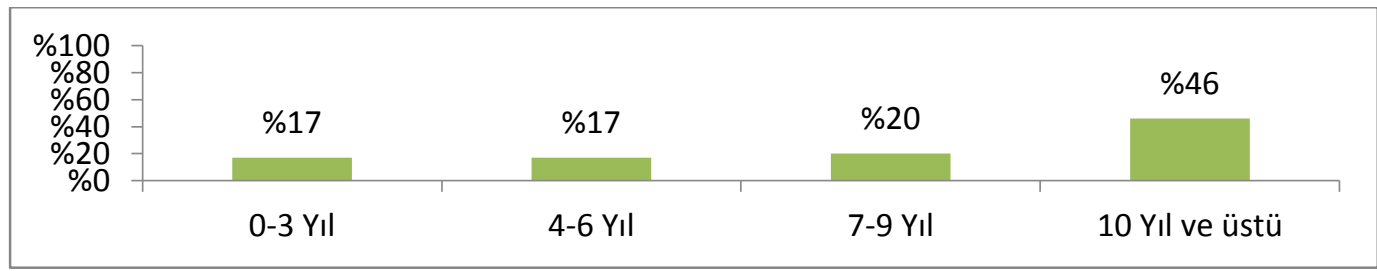

Şekil 29. “Kaç yıldır bu konutta oturuyorsunuz?” Sorusuna verilen cevapların grafiği.

"Oturduğunuz konutun mülkiyet durumu nedir?" Sorusuna \%96 ev sahibi, \%4 kiracı cevabı verilmiştir (Şekil 30).

\begin{tabular}{|c|c|c|}
\hline \multirow[t]{2}{*}{$\begin{array}{r}\% 100 \\
\% 80 \\
\% 60 \\
\% 40 \\
\% 20 \\
\% 0\end{array}$} & \%96 & $\% 4$ \\
\hline & Ev sahibi & Kiracı \\
\hline
\end{tabular}

Şekil 30. “Oturduğunuz konutun mülkiyet durumu nedir?” Sorusuna verilen cevapların grafiği.

“Katılımcıların daha önce oturduğunuz konut tipi nedir?” Sorusuna verdikleri cevaplar \% 58 şehir içi apartman dairesi, \%35 toplu konut apartman dairesi, \%8 müstakil ev şeklindedir (Şekil 31). 


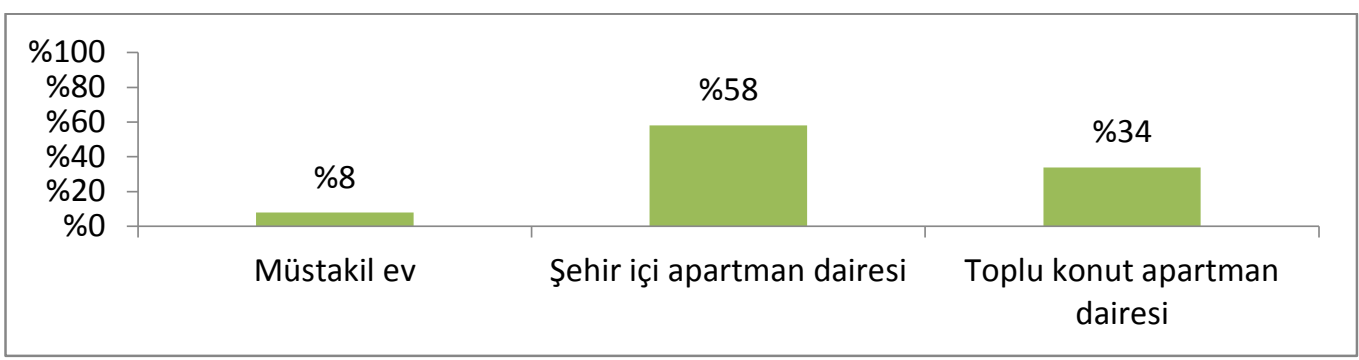

Şekil 31. "Daha önce oturduğunuz konut tipi nedir?” Sorusuna verilen cevapların grafiği.

\section{Tartışma ve Sonuç}

Cumhuriyet Döneminin başlangııından günümüze değin geçen süreç içerisinde ev bahçelerinin düzenlenmesinde daha önceki dönemlerdeki ev bahçesi anlayışına uygun bazı özellikler korunmuştur. Ancak günümüzdeki ev bahçesi örnekleri irdelendiğinde, peyzaj düzenlemesine ilişkin anlayışta birçok değişiklikler saptanmıştır.

Araştırma sonuçları açısından yapılan literatür araştırması ve görsel saptamalar ile villa sakinlerine uygulanan anket çalışmasından elde edilen sonuçlar öncelikle ayrı ayrı değerlendirilmiştir. Daha sonra da tüm sonuçlar değerlendirilerek öneriler getirilmeye çalışılmıştır.

\subsection{Literatür Araştırması ile Görsel Saptamalar Sonrasında Ulaşılan Sonuçların Değerlendirilmesi}

-Eski Türk bahçelerindeki mahremiyet ve gizlilik olgusunun günümüz ev bahçelerinde yapısal ve bitkisel elemanlarla bahçe sınırlarını belirginleştiren duvar ve çit oluşturma anlayışıyla sürdüğü belirlenmiştir.

-Günümüzdeki ev bahçesi örneklerindeki ön bahçe ve arka bahçe tasarım ve kullanım biçimleri Eski Türk bahçelerindeki ön bahçe anlayışında farklıdır. Eski Türk bahçelerinde avlu ya da hayat olarak isimlendirilen ön bahçe özel bir açık hava yaşam mekânı iken günümüzdeki örneklerde bu işlevi arka bahçe görmektedir.

-Türk bahçesindeki gezinti bahçesinden çok oturma bahçesi olması anlayışı günümüzdeki örneklerde de devam etmektedir.

-Eski Türk bahçelerinde plan elemanlarının simetriğe dayalı bir plan ortaya koymaması şekli günümüz ev bahçesi örneklerinde de görülmektedir. Bahçe yalnızca seyretme amacıyla değil, yaşanacak mekânlar şeklinde tasarlanmaktadır.

-işlevselliğin önemli olduğu Türk bahçelerinde oluşturulan sebze bahçeleri ve bitkisel tasarımında meyve ağaçlarının da kullanılması, bahçe büyüklüğüyle orantılı olarak günümüzdeki örneklerde de devam etmektedir.

-Su elemanı olarak süs havuzu ve çeşmenin kullanımı günümüzdeki örneklerde yüzme havuzuyla çeşitlendirilmektedir.

-Sebze bahçeleri, meyve ağaçları, çiçek tarhları ile geniş tepe çapına ait ağaçların ve duvar boyunca dikilen ağaçların kullanıldığı bitkisel eleman seçimleri geçmişin aksine, günümüzde yerini ağırıklı olarak ithal bitki seçimlerine bırakmaya başlamıştır.

\subsection{Villa Sakinlerine Uygulanan Anket Çalışmasından Elde Edilen Sonuçlar}

- Villa sakinlerinin yaşamış oldukları sitenin ortak yeşil alanlarından ziyade çoğunlukla kendi özel konut bahçelerini kullandıkları saptanmıştır.

-Bahçelerinde dinlenme alanı ve spor alanı öncelikli fonksiyon tercihleri olmuştur.

-Evlerinin bahçelerini en çok yaz döneminde ve hafta sonu kullandıkları belirlenmiştir.

-Oturma grupları ile bitkisel elemanlar en çok istenen donatı elemanları olarak sıralanmıştır.

-Bitkisel eleman tercihleri sorulduğunda, çiçekli ağaçlar, iğne yapraklı ağaçlar, çim alanlar ve mevsimlik çiçekler olarak sıralamışlardır. 
-Bahçe sınırlarının özellikle kafes tel ya da bitkisel çit ile belirlenmesini istemişlerdir. Bahçelerinin peyzaj düzenlemesinin gerekliliğine ve konuta görsel-ekonomik değer kattı̆ı̆na inandıklarını belirtmelerine karşın düzenleme ve bakımlarında peyzaj mimarlarından daha çok bahçıvanlarla çalıştıklarını belirtmişlerdir.

-Oturdukları yerleşkenin sakinleri arasında sosyo-ekonomik ve kültürel yönden farklılıklar olduğu belirtilmiş ve sosyalleşme problemleri yaşandığını söylemişlerdir.

\subsection{Günümüzdeki Ev Bahçelerinde Güncel Eğilimlerin İrdelenmesi}

Günümüzdeki ev bahçeleri anlayışına ilişkin değerlendirme ve önerileri şu şekilde sıralayabiliriz:

-Konut yapıldıktan sonra bahçenin yapılması, en belirgin tasarım problemi olarak saptanmıştır. Oysaki mimar ve peyzaj mimarı işbirliği ile konut ve bahçenin birlikte ve bir bütün olarak tasarıma dâhil edilmesi daha doğru olacaktır.

-Ev bahçesinin peyzaj düzenlemesi çoğunlukla villa sakinlerinin kültürel ve sosyo-ekonomik yapısının etkisi ile şekillenmektedir. Bu durumun önlenmesi için peyzaj mimarlarının müşterilerine eğitici ve yönlendirici tavır sergilemeleri gerekmektedir.

-Suyun geçmiş kullanımlarına baktığımızda çeşme, süs amaçlı havuz, şadırvan ve çağlayanlar şeklinde olduğu görülmektedir. Günümüzde yeni tasarım anlayışlarının girişi ile peyzaja zenginlik katan su ögelerinin yüzme amaçı kullanılması yaklaşımları da gittikçe artan ve olumlu gelişmeler olarak belirlenmiştir.

-Mülkiyetçi bir anlayışla ön bahçelerde duvarlarla ve çitlerle sınır belirginleştirme anlayışı yerine ön bahçelerin ortak bir yeşil alan görüntüsü oluşturmasına yönelik çalışmalar ivedilikle gerçekleştirilmelidir.

-Bitkisel eleman tercihlerinde bakım istekleri fazla olan, dayanıklıkları da doğal türler kadar olmayan ve de yörenin kimliğini olumsuz etkileyen ithal bitki kullanımının yaygınlığı azaltılmalıdır.

\section{Kaynaklar}

Akdoğan, G. (1974). Bahçe ve Peyzaj Sanat Tarihi, Ankara Üniversitesi Ziraat Fakültesi Yayınları Ders Kitabı, Ankara.

Akyol, M., Kaya, M., E. (2016). Geçmişten Günümüze Türk Kültüründe Ev Bahçesi Anlayışı Üzerine Araştırmalar, Türk Bahçeleri ve Çağdaş Dönem Kent İçi Bahçe Uygulamaları, 2016, İstanbul, ISBN: 978-975-561-470-0, 341-352.

Altunkasa, M.F. (1998). Peyzaj Mimarlığı, Çukurova Üniversitesi Ziraat Fakültesi Yardımcı Ders Kitabı No: D-19, 60s, Adana.

Avcı, Ü. (2005). Antalya kenti geleneksel Türk konutlarında bahçe mekânının analizi, Yüksek Lisans Tezi, Akdeniz Üniversitesi Fen Bilimleri Enstitüsü.

Aydıngün, M. S. (1997). Konut Yakın Çevre Oluşumuna Bir Yaklaşım, Yüksek Lisans Tezi Hacettepe Üniversitesi Sosyal Bilimler Enstitüsü.

Eldem, S. H. (1976),.Türk Bahçeleri, Milli Eğitim Basımevi, İstanbul.

Erdem N. (1990). Tarihsel Süreç İçerisinde Konut Bahçelerinin İrdelenmesi ve İstanbul Örnekleri, Yüksek Lisans Tezi, Yıldız Teknik Üniversitesi Fen Bilimleri Enstitüsü.

Erdem, N. (1994). I..Ü. Orman Fakültesi Dergisi, Tarihsel Süreç içerisinde Konut Bahçelerinin İrdelenmesi ve ìstanbul Örnekleri, 131-152.

Ertin, D. G. (2011) Geleneksel Edirne evlerinin bahçe düzenleri, Yüksek Lisans Tezi, Trakya Üniversitesi Fen Bilimleri Enstitüsü.

Evyapan, G. A. (1972). Eski Türk Bahçeleri ve Özellikle Eski İstanbul Bahçeleri, Orta Doğu Teknik Üniversitesi Yayını, Ankara.

Evyapan, G. A. (1974). Tarih İçinde Formel Bahçenin Gelişimi ve Türk Bahçesinde Etkileri, Orta Doğu Teknik Üniversitesi Yayını, Ankara. 
Gedikli, R. (1993). Trabzon kenti geleneksel konutlarında konut - bahçe ilişkisi üzerine bir inceleme, Yüksek Lisans Tezi, Karadeniz Teknik Üniversitesi Fen Bilimleri Enstitüsü.

Gülez, S. (1989). Park bahçe ve peyzaj mimarisi, Karadeniz Teknik Üniversitesi Orman Fakültesi Ders Teksirleri Serisi 29, Trabzon.

Gültekin, E. (1998). Bahçe ve Peyzaj Sanat Tarihi; Türk-İslam Bahçeleri, Çukurova Üniversitesi Ziraat Fakültesi Genel Yayınları No: 22, Adana.

Gürer, N. (2003). Kırsal Geleneksel Konut Dokusunun Turizm Bağlamında Değerlendirilmesi, Cumalıkızık Örneği, Yüksek Lisans Tezi, Gazi Üniversitesi Fen Bilimleri Enstitüsü.

Hasol, D. (1993). Mimarlık ve Yapı Terimleri Sözlüğü: Türkçe-İngilizce-Fransızca. Yapı Endüstri Merkezi.

Kartal, B. (2009). İstanbul'daki tarihi saray bahçelerinin peyzaj mimarlığı açısından incelenmesi, İstanbul Üniversitesi Fen Bilimleri Enstitüsü.

Kayakent, T. (1999). Tarih İçinde Bahçe Olgusu ve Eski Türk Bahçelerinin Günümüz Bahçelerine Dönüşüm Süreci, Yüksek Lisans Tezi, İstanbul Teknik Üniversitesi Fen Bilimleri Enstitüsü.

Kuş Şahin, C. (2008). Isparta Kent Merkezi Konut Bahçelerindeki Bitkisel Materyalin İncelenmesi Üzerine Bir Araştırma, Doktora Tezi, Süleyman Demirel Üniversitesi Fen Bilimleri Enstitüsü.

Mutluer, M. (2000). Kentleşme Sürecinde İzmir'de Toplu Konut Uygulamaları ve Sorunlar, Ege Üniv. Edebiyat Fakültesi Yay. No: 99.

Öztan, Y. (2004). Yaşadığımız Çevre ve Peyzaj Mimarlığı, Tisamat Basım Sanayi, Ankara.

Perker, Z., S., ve Akıncıtürk, N. (2011). Geleneksel Cumalıkızık Evlerinde ahşap konut sistemi, Uludağ Üniversitesi Mühendislik-Mimarlık Fakültesi Dergisi, Cilt 16, Sayı 1.

Saygıcı, S. (2004). Üst gelir grubuna yönelik tasarlanan konut alanlarının değerlendirilmesi, Yüksek Lisans Tezi, İstanbul Teknik Üniversitesi Fen Bilimleri Enstitüsü.

Tanrıverdi, F. (1975). Peyzaj Mimarisi Bahçe Sanatının Temel Prensipleri ve Uygulama Metodları, Atatürk Üniversitesi yayınları No:148, Ziraat Fakültesi yayınları No: 196. Sevinç Matbaası, Ankara.

Tanrıverdi, F. (1987). Peyzaj mimarlığı: bahçe sanatının temel ilkeleri ve uygulama metodları, Atatürk Üniversitesi, Ziraat Fakültesi yayınları; no.291, Erzurum.

Taşkan, G. (2014). Bartın kenti geleneksel konutlarındaki yapısal değişimlerin bahçe mekânı ve kullanılan bitki materyaline yansımaları, Yüksek Lisans Tezi, Bartın Üniversitesi Fen Bilimleri Enstitüsü.

Ünlükara, T. (2008). Lüks konutlarda satış fiyatını etkileyen faktörlerin incelenmesi: İstanbul örneği, Yüksek Lisans Tezi, İstanbul Teknik Üniversitesi Fen Bilimleri Enstitüsü.

Wallace, M., Küçükerbaş, E., V. (2016). Geçmişten Günümüze Türk Kültüründe Ev Bahçesi Anlayışı Üzerine Araştırmalar, Türkiye Peyzajları I. Ulusal Konferansı Türk Bahçeleri Bildiri Kitabı, 2016, İstanbul, ISBN: 978-975-561-470-0, 341-352.

Yahşi, E. (2007). Konut değerlemesi ve konut değerlerini etkileyen faktörlerin regresyon analizi ile incelenmesi, Yüksek Lisans Tezi, İstanbul Teknik Üniversitesi Fen Bilimleri Enstitüsü.

Yeşil, M., Yılmaz, S. (2007). Erzurum Kentinde Konut Bahçelerinin Peyzaj Tasarım Illkelerine Göre İncelenmesi Üzerine Bir Araştırma. Atatürk Üniversitesi Ziraat Fakültesi Dergisi, 38 (1), 25-35.

Zeybekoğlu, D. (2005). Edirne Geleneksel Konut Mimarlığını Etkileyen Sosyo-Kültürel Faktörlerin İncelenmesi, Yüksek Lisans Tezi, Trakya Üniversitesi Fen Bilimleri Enstitüsü. 